\title{
PET Imaging of Neuroinflammation in Alzheimer's Disease
}

\author{
Rong Zhou ${ }^{1 \dagger}$, Bin $\mathrm{Ji}^{2 \dagger}$, Yanyan Kong ${ }^{3}$, Limei Qin ${ }^{4}$, Wuwei Ren ${ }^{5}$, Yihui Guan ${ }^{3 *}$ \\ and Ruiqing $\mathrm{Ni}^{6,7 *}$
}

1 Department of Nephrology, Yangpu Hospital, School of Medicine, Tongji University, Shanghai, China, ${ }^{2}$ Department of Radiopharmacy and Molecular Imaging, School of Pharmacy, Fudan University, Shanghai, China, ${ }^{3}$ Positron Emission Tomography (PET) Center, Huashan Hospital, Fudan University, Shanghai, China, ${ }^{4}$ Inner Mongolia Baicaotang Qin Chinese Mongolia Hospital, Hohhot, China, 5 School of Information Science and Technology, Shanghaitech University, Shanghai, China, ${ }^{6}$ Institute for Regenerative Medicine, University of Zurich, Zurich, Switzerland, ${ }^{7}$ Institute for Biomedical Engineering, University of Zurich \& Eidgenössische Technische Hochschule Zürich (ETH Zurich), Zurich, Switzerland

OPEN ACCESS

Edited by:

Maya Koronyo-Hamaoui, Cedars Sinai Medical Center, United States

Reviewed by:

Neil Vasdev,

Centre for Addiction and Mental Health (CAMH), Canada

Nazanin Mirzaei,

Life Molecular Imaging $\mathrm{GmbH}$,

Germany

*Correspondence: Yihui Guan

guanyihui@hotmail.com

Ruiqing Ni

ruiqing.ni@uzh.ch

${ }^{\dagger}$ These authors have contributed equally to this work

Specialty section: This article was submitted to Multiple Sclerosis

and Neuroimmunology,

a section of the journal

Frontiers in Immunology

Received: 10 July 2021 Accepted: 27 August 2021 Published: 16 September 2021

Citation:

Zhou R, Ji B, Kong Y, Qin L, Ren W,

Guan $Y$ and Ni R (2021) PET

Imaging of Neuroinflammation

in Alzheimer's Disease.

Front. Immunol. 12:739130. doi: 10.3389/fimmu.2021.739130
Neuroinflammation play an important role in Alzheimer's disease pathogenesis. Advances in molecular imaging using positron emission tomography have provided insights into the time course of neuroinflammation and its relation with Alzheimer's disease central pathologies in patients and in animal disease models. Recent single-cell sequencing and transcriptomics indicate dynamic disease-associated microglia and astrocyte profiles in Alzheimer's disease. Mitochondrial 18-kDa translocator protein is the most widely investigated target for neuroinflammation imaging. New generation of translocator protein tracers with improved performance have been developed and evaluated along with tau and amyloid imaging for assessing the disease progression in Alzheimer's disease continuum. Given that translocator protein is not exclusively expressed in glia, alternative targets are under rapid development, such as monoamine oxidase $\mathrm{B}$, matrix metalloproteinases, colony-stimulating factor 1 receptor, imidazoline-2 binding sites, cyclooxygenase, cannabinoid-2 receptor, purinergic P2X7 receptor, P2Y12 receptor, the fractalkine receptor, triggering receptor expressed on myeloid cells 2 , and receptor for advanced glycation end products. Promising targets should demonstrate a higher specificity for cellular locations with exclusive expression in microglia or astrocyte and activation status (pro- or anti-inflammatory) with highly specific ligand to enable in vivo brain imaging. In this review, we summarised recent advances in the development of neuroinflammation imaging tracers and provided an outlook for promising targets in the future.

Keywords: Alzheimer's disease, neuroinflammation, tau, microglia, astrocyte, amyloid (A) 42, positron emission tomography (PET), TSPO (18 kDa translocator protein)

\section{INTRODUCTION}

Neurodegenerative diseases, including Alzheimer's disease (AD), frontotemporal dementia, Parkinson's disease (PD), and Lewy body dementia, represent a tremendous unmet clinical need. The major neuropathological features of $\mathrm{AD}$ are the deposition of amyloid-beta $(\mathrm{A} \beta)$ plaques, neurofibrillary tangles formed by misfolded hyperphosphorylated tau, neuronal loss, and 
neuroinflammation characterised by glial activation $(1,2)$. Neuroinflammation plays an important role in $\mathrm{AD}$; however, its dynamics and impacts (protective or detrimental) have still not been fully elucidated $(3,4)$. Microglia, as the resident macrophage cells in the brain, have emerged as central players in the $\mathrm{AD}$ pathogenesis $(1,2,5)$. Microglial activation was previous classified into proinflammatory (M1) or anti-inflammatory (M2) types (2). Recent single-cell sequencing and transcriptomics studies reported gene coexpression network diversity of microglia in $\mathrm{AD}$ and disease-associated-microglia (DAM) of transcriptionally distinct and neurodegeneration-specific profiles (6-12). A $\beta$-laden microglia has a unique gene-expression signature including triggering receptor expressed on myeloid cells 2 (TREM2), apolipoprotein $\mathrm{E}$ (ApoE), and other $\mathrm{AD}$-associated genes (13, 14). Microglia phagocytosis driven by Tyro3, Axl, and Mer (TAM) receptor has been shown to promote the development of densecore plaque and the engulfing of $\mathrm{A} \beta$ plaques (15). Astrocytes are categorised into A1 and A2 subtypes based on their phenotype and genetic expression profiles (16-19). A1 astrocyte secretes and produces a large number of inflammatory factors and neurotoxins, whereas A2 astrocyte produces neurotrophic substances and supports neuronal growth. Reactive astrocytes precipitate both $A \beta$ and tau (20-22) and are closely linked with microgliosis (16). Cerebrospinal fluid (CSF) and plasma biomarkers for neurodegeneration and inflammatory markers [e.g., tumor necrosis factor alpha (TNF $\alpha$ ), interleukin-6 (IL-6), IL-10] were elevated in patients with $\mathrm{AD}$ and mild cognitive impairment (MCI) compared to healthy controls $(6,7,13,14)$, associated with an increasing age $(23,24)$ and cerebral amyloid pathology (25). Recent advances in molecular imaging have provided insights into the time course of $\mathrm{AD}$ pathology, including $A \beta$, tau, synaptic deficits, and neuroinflammation, in patients and in animal disease models $(1,26-35)$. In vivo imaging of neuroinflammation, however, is challenging, and the spatialtemporal pattern in the development of $\mathrm{AD}$ has still not been fully elucidated (23). One reason is that the astrocytes and microglia are highly dynamic and heterogeneous in their subtypes, locations, and activation status (1).

\section{NEUROINFLAMMATION POSITRON EMISSION TOMOGRAPHY IMAGING}

Mitochondrial $18 \mathrm{kDa}$ translocator protein (TSPO) is the most widely investigated neuroinflammation target for PET imaging (36). Other alternative targets are under rapid development (Table 1), such as monoamine oxidase-B (MAO-B), matrix metalloproteinases (144-147, 185, 186), colony-stimulating factor 1 receptor (CSF1R), imidazoline-2 binding sites $\left(\mathrm{I}_{2} \mathrm{BS}\right)$, cyclooxygenases, the phospholipase A2/arachidonic acid pathway, sphingosine-1-phosphate receptor-1, reactive oxygen species, cannabinoid-2 receptor, purinergic $\mathrm{P} 2 \mathrm{X} 7$ receptor and P2Y12 receptor, the fractalkine receptor (CX3CR1) (187), TREM2 (140), and receptor for advanced glycation end products $(36,188)$ (Table 1).

\section{TSPO Imaging}

TSPO is expressed mainly in the outer mitochondrial membrane of steroid-synthesizing cells in the central nervous system (microglia, astrocytes, endothelial cell, etc.) (Figures 1A, B) and in the peripheral (191). TSPO is involved in many physiological processes including transporting cholesterol into mitochondria, steroid hormone synthesis, and bioenergetics (191, 192). Upregulation of TSPO was found in patients with $\mathrm{AD}$ and in animal models of $\mathrm{AD}(92,193)$.

\section{The First Generation TSPO Tracers}

The first-generation tracers exemplified with $\left[{ }^{11} \mathrm{C}\right] \mathrm{PK}-11195$ have been widely used in preclinical and clinical studies. However, $\left[{ }^{11} \mathrm{C}\right]$ PK-11195 suffers from several major limitations such as low permeability of the blood-brain barrier and high non-specific plasma binding, leading to a low signal-to-noise ratio in the final reconstructed PET images (194). Careful analysis of plasma metabolites is required to determine the accurate arterial input function for quantitative PET measurement (195). Increased $\left[{ }^{11} \mathrm{C}\right]$ PK11195 is reported to be associated with $A \beta$ accumulation in patients with MCI and AD compared to healthy controls, correlating with the deficits in functional network connectivity, grey matters atrophy, and cognitive decline $(37-39,196)$. Using $\left[{ }^{11} \mathrm{C}\right] \mathrm{PK} 11195$, recent studies have showed a biphasic trajectory of inflammation with an early microglial activation with increasing $\mathrm{A} \beta$ load and a later decline when $\mathrm{A} \beta$ load reaching plateau (AD) levels (40). Ismail et al. demonstrated a parallel increase in microglial activation and tau accumulation assessed by $\left[{ }^{11} \mathrm{C}\right]$ PK11195 and $\left[{ }^{18} \mathrm{~F}\right]$ flortaucipir, respectively, in $\left[{ }^{11} \mathrm{C}\right] \mathrm{PIB} \mathrm{A} \beta$ positive MCI patients (41). Su et al. further showed that grey matter atrophy mediated the effects of tau accumulation and neuroinflammation detected by PET tracers $\left[{ }^{18} \mathrm{~F}\right]$ flortaucipir and $\left[{ }^{11} \mathrm{C}\right] \mathrm{PK} 11195$, respectively on cognitive impairments in AD (42).

\section{The Second Generation TSPO Tracers}

A few second generation tracers including $\left[{ }^{11} \mathrm{C}\right] \mathrm{DAA} 1106,\left[{ }^{1} \mathrm{~F}\right]$ FEDAA1106, $\left[{ }^{125} \mathrm{I}\right] \mathrm{CLINDE}\left[{ }^{11} \mathrm{C}\right] \mathrm{PBR} 06,\left[{ }^{11} \mathrm{C}\right] \mathrm{PBR} 28,\left[{ }^{18} \mathrm{~F}\right]$ PBR111, $\left[{ }^{18} \mathrm{~F}\right]$ DPA-713, $\left[{ }^{18} \mathrm{~F}\right] \mathrm{DPA}-714,\left[{ }^{18} \mathrm{~F}\right] \mathrm{F}-\mathrm{DPA},\left[{ }^{11} \mathrm{C}\right] \mathrm{AC}-$ 5216, $\left[{ }^{18} \mathrm{~F}\right] \mathrm{FEMPA}$, and $\left[{ }^{18} \mathrm{~F}\right] \mathrm{FEPPA}$ have been developed to overcome the limitations of $\left[{ }^{11} \mathrm{C}\right] \mathrm{PK} 11195$ (45, 46, 52, 61-63, 66, 69-71, 83, 84, 197) (Table 1). However, the binding affinities of second generation TSPO tracers in human brain differ based on the rs6971 polymorphisms, which introduces higher variability between subjects $(45,46,52,61-63,66,69-71,197)$. In addition, the $\left[{ }^{11} \mathrm{C}\right]$ PBR28 binding appears to be affected by chromosome 1 variant rs2997325 on microglial activation (198). Several longitudinal studies using $\left[{ }^{18} \mathrm{~F}\right] \mathrm{DPA}-714,\left[{ }^{11} \mathrm{C}\right] \mathrm{DAA} 1106$, and $\left[{ }^{11} \mathrm{C}\right] \mathrm{PBR} 28$ have reported decreased glucose metabolism and increased neuroinflammation in amyloidosis, four-repeat tauopathy animal models (47-50, 55) (Table 1). Ishikawa et al. has indicated an association between tau assessed by $\left[{ }^{11} \mathrm{C}\right] \mathrm{PBB} 3$, neuronal damage measured by structural MRI, and neuroinflammation detected by using $\left[{ }^{11} \mathrm{C}\right] \mathrm{AC}-5216$ in rTg4510 mice (56-58). Chaney et al. showed an increased $\left[{ }^{18} \mathrm{~F}\right] \mathrm{DPA}-714$ binding and myo-inositol levels using ${ }^{1} \mathrm{H}$ magnetic resonance spectroscopy in APP/PS1 mice (48). Zou et al. showed that microglial activation assessed by $\left[{ }^{11} \mathrm{C}\right] \mathrm{PBR} 28$ is independently associated with amyloid load and memory 
TABLE 1 | Summary of imaging probes for gliosis.

\begin{tabular}{|c|c|c|c|}
\hline Target & Tracer & Human & Animal model \\
\hline \multirow[t]{19}{*}{ TSPO } & $(\mathrm{R})-\left[{ }^{11} \mathrm{C}\right] \mathrm{PK} 11195$ & $\mathrm{MCl}, \mathrm{AD}, \mathrm{HC}(37-43)$ & $3 \times T g$, APP/PS1 mice, $r \operatorname{Tg} 4510$ mice $(26,44)$ \\
\hline & {$\left[{ }^{18} \mathrm{~F}\right] \mathrm{DPA}-714$} & AD, MS, ALS, HC $(45,46)$ & APP/PS1 mice, TgF344 rats (47-51) \\
\hline & {$\left[{ }^{11} \mathrm{C}\right] \mathrm{DPA}-713$} & $A D, H C(52)$ & Murine stroke models (53), aged Monkeys (54) \\
\hline & {$\left[{ }^{18} \mathrm{~F}\right] \mathrm{F}-\mathrm{DPA}$} & & APP/PS1 mice (55) \\
\hline & {$\left[{ }^{18} \mathrm{~F} F E B M P\right.$} & & PS19, rTg4510 mice (56-58) \\
\hline & $\begin{array}{l}{\left[{ }^{11} \mathrm{C}\right] \mathrm{DAA} 1106} \\
{\left[{ }^{18} \mathrm{~F}\right] \mathrm{FEDAA} 1106}\end{array}$ & $\mathrm{AD}, \mathrm{HC}$ & APP23, APP/PS1, PS19 mice, TgF334 rats $(50,59,60)$ \\
\hline & {$\left[{ }^{18} \mathrm{~F}\right] \mathrm{FEMPA}$} & $\mathrm{AD}, \mathrm{HC}(61,62)$ & \\
\hline & {$\left[{ }^{11} \mathrm{C}\right] \mathrm{AC}-5216$} & $\mathrm{HC}(63)$ & 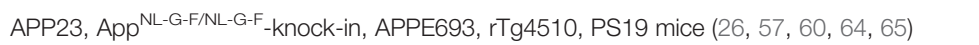 \\
\hline & {$\left[{ }^{18} \mathrm{~F}\right] \mathrm{FEPPA}$} & $\mathrm{MCl}, \mathrm{AD}, \mathrm{HC}(66,67)$ & TgAPP21 rats (68) \\
\hline & {$\left[{ }^{11} \mathrm{C}\right] \mathrm{PBR} 06$} & $\mathrm{MCl}, \mathrm{AD}, \mathrm{HC}(69-71)$ & APP $^{L / S}$ mice $(57,72,73)$ \\
\hline & {$\left[{ }^{11} \mathrm{C}\right] \mathrm{PBR} 28$} & $\begin{array}{l}\text { AD, SD, MCl, FTD, DLB, ALS, } \\
\mathrm{HC}(40,69,74-82)\end{array}$ & $5 \times F A D, P S 19$ mice $(57,73)$ \\
\hline & {$\left[{ }^{18} \mathrm{~F}\right] \mathrm{PBR} 111$} & & APP/PS1 mice $(83,84)$ \\
\hline & {$\left[{ }^{125} \mid\right] C L I N D E$} & AD, HC (85) & LPS injected, $3 \times \operatorname{Tg}$ mice, TgF344 rats (85-87) \\
\hline & {$\left[{ }^{18} \mathrm{~F}\right] \mathrm{GE}-180$} & AD, MS, FTD, HC (88-91) & $\begin{array}{l}\text { APP/PS1, PS2APP, APP23, APP-SL70, APPswe, APP }{ }^{N L-G-F} \text {, APP }{ }^{L / S} \text {, Trem2 p.T66M knock- } \\
\text { in, PS19 mice, TgF344 rats }(47,50,53,90,92-102)\end{array}$ \\
\hline & $\begin{array}{l}(\mathrm{S})-\left[{ }^{18} \mathrm{~F}\right] \mathrm{GE}-387,(\mathrm{R}, \mathrm{S})- \\
{\left[{ }^{18} \mathrm{~F}\right] \mathrm{GE}-387}\end{array}$ & $\mathrm{HC}(103)$ & LPS injected rats, non-human primates $(103,104)$ \\
\hline & {$\left[{ }^{11} \mathrm{C}\right] \mathrm{ER} 176$} & $\mathrm{HC}(75,105,106)$ & \\
\hline & {$\left[{ }^{11} \mathrm{C}\right] \mathrm{CB} 184,\left[{ }^{11} \mathrm{C}\right] \mathrm{CB} 190$} & & Mice, 6-OHDA injected rats (107) \\
\hline & {$\left[{ }^{11} \mathrm{C}\right] \mathrm{N}^{\prime}-\mathrm{MPB}$} & & Stroke rat model (108) \\
\hline & {$\left[{ }^{18} \mathrm{~F}\right] \mathrm{LW} 223$} & HC (109) & Rats (109) \\
\hline \multirow[t]{5}{*}{$\mathrm{P} 2 \mathrm{X} 7 \mathrm{R}$} & {$\left[{ }^{11} \mathrm{C}\right] \mathrm{GSK} 1482160$} & HC (110) & LPS-injected mice, EAE rats, non-human primates $(110,111)$ \\
\hline & {$\left[{ }^{18} \mathrm{~F}\right] \mathrm{JNJ}-64413739$} & HC (112), ALS (113) & LPS injected mice $(112,114)$ \\
\hline & {$\left[{ }^{11} \mathrm{C}\right] J N J-54173717$} & ALS (113) & rAAV3flag-hP2X7R, $\alpha$-synuclein, 6-OHDA injected rats, non-human primates $(115,116)$. \\
\hline & {$\left[{ }^{11} \mathrm{C}\right] \mathrm{SMW} 139$} & MS (117) & EAE, rAAV3flag-hP2X7R rats $(118,119)$ \\
\hline & $\begin{array}{l}{\left[{ }^{11} \mathrm{C}\right] J N J-47965567} \\
(\mathrm{~A}-740003)\end{array}$ & MS (120) & Rats (121) \\
\hline \multirow[t]{3}{*}{ P2Y12R } & {$\left[{ }^{11} \mathrm{C}\right] \mathrm{P} 2 \mathrm{Y} 12 \mathrm{R}$-ant } & MS (120) & EAE rats $(120)$ \\
\hline & {$\left[{ }^{11} \mathrm{C}\right] 5$} & Stroke (122) & Murine stroke model (122) \\
\hline & {$\left[{ }^{11} \mathrm{C}\right] A Z D 1283$} & & rTg4510, PS19, APP23, and APP ${ }^{N L-F / N L-F}$ mice, ex vivo (123) \\
\hline \multirow[t]{2}{*}{ CSF1R } & {$\left[{ }^{11} \mathrm{C}\right] \mathrm{CPPC}$} & $A D, H C(124)$ & 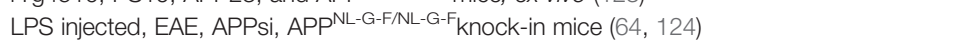 \\
\hline & {$\left[{ }^{11} \mathrm{C}\right] \mathrm{GW} 2580$} & & LPS injected, APP ${ }^{N L-G-F / N L-G-F}$ knock-in mice, non-human primates (64) \\
\hline \multirow[t]{2}{*}{$\mathrm{COX}-1$} & {$\left[{ }^{11} \mathrm{C}\right]-\mathrm{KTP}-\mathrm{Me}$} & $\mathrm{AD}, \mathrm{HC}(125,126)$ & APPswe mice (125-127) \\
\hline & {$\left[{ }^{11} \mathrm{C}\right] \mathrm{PS} 13,\left[{ }^{18} \mathrm{~F}\right] \mathrm{PS} 2$} & & LPS treated rhesus macaques (128) \\
\hline \multirow[t]{3}{*}{$\mathrm{COX}-2$} & {$\left[{ }^{11} \mathrm{C}\right] \mathrm{MC} 1$} & & LPS treated rhesus macaques (129) \\
\hline & {$\left[{ }^{18} \mathrm{~F}\right] \mathrm{FMTP}$} & & LPS injected mice (130) \\
\hline & {$\left[{ }^{18} \mathrm{~F}\right] \mathrm{TMl}$} & & Non-human primates (131) \\
\hline iNOS & {$\left[{ }^{18} \mathrm{~F}\right] \mathrm{FBAT}$} & & LPS injected mice (132) \\
\hline \multirow[t]{5}{*}{ ROS } & $\begin{array}{l}{\left[{ }^{18} \mathrm{~F} \text { ROStrace }\left[{ }^{18} \mathrm{~F}\right] \mathrm{ox}-\right.} \\
\text { ROStrace. }\end{array}$ & & LPS-treated mice (133) \\
\hline & {$\left[{ }^{18}\right.$ F]dihydromethidine, } & & LPS-treated mice (134) \\
\hline & {$\left[{ }^{11} \mathrm{C}\right]$ Ascorbic. $\left[{ }^{11} \mathrm{C}\right]$} & & Rats (135) \\
\hline & dehydroascorbic acid & & \\
\hline & {$\left[{ }^{62} \mathrm{Cu}\right] \mathrm{ATSM}$} & PD, ALS, MELAS $(136,137)$ & Brain tumor mice $(138,139)$ \\
\hline TREM-2 & $\begin{array}{l}\left.{ }^{124} \mathrm{l}\right] \mathrm{mAb} 1729, \mathrm{mAb} 1729- \\
\text { scFv8D3CL }\end{array}$ & & APPArcSwe, APPswe mice (140) \\
\hline \multirow[t]{2}{*}{ TREM-1 } & {$\left[{ }^{64} \mathrm{Cu}\right] \mathrm{TREM} 1-\mathrm{mAb}$} & & Murine stroke, MS, GBM models (141-143) \\
\hline & & & Murine glioma and metastatic breast cancer model (144-146) \\
\hline MMP & {$\left[{ }^{18} \mathrm{~F}\right] \mathrm{BR}-351,\left[{ }^{18} \mathrm{~F}\right] \mathrm{BR}-420$} & & Murine stroke models $(147,148)$ \\
\hline \multirow[t]{5}{*}{$\mathrm{CB}_{2} \mathrm{R}$} & {$\left[{ }^{11} \mathrm{C}\right] \mathrm{A}-836339,\left[{ }^{18} \mathrm{~F}\right] 2 \mathrm{f}$} & $\mathrm{HC}(149)$ & J20APPswe/ind, APP/PS1 mice (150) \\
\hline & {$\left[{ }^{18} \mathrm{~F}\right] \mathrm{RS}-126,\left[{ }^{18} \mathrm{~F}\right] \mathrm{RoSMA}-$} & & LPS injected, Huntington, stroke mice $(151,152)$ \\
\hline & $18-\mathrm{d} 6$ & & \\
\hline & {$\left[{ }^{18} \mathrm{~F}\right] J H \cup 94620$} & & LPS injected mice (153) \\
\hline & {$\left[{ }^{11} \mathrm{C}\right] \mathrm{NE} 40$} & AD, $\mathrm{HC}(154)$ & SAMP10 mice (155) \\
\hline \multirow[t]{4}{*}{ MAO-B } & {$\left[{ }^{11} \mathrm{C}\right] \mathrm{DED}$} & $\mathrm{MCl}, \mathrm{AD}, \mathrm{HC}(156-162)$ & APPArcSwe, APPswe mice $(163,164)$ \\
\hline & {$\left[{ }^{18} \mathrm{~F}\right]$ fluorodeprenyl-D2 } & & Non-human primates (165) \\
\hline & {$\left[{ }^{18} \mathrm{~F}\right] \mathrm{SMBT}-1$} & $\mathrm{AD}, \mathrm{HC}(166,167)$ & \\
\hline & {$\left[{ }^{11} \mathrm{C}\right] \mathrm{SL} 25.1188$} & HC, MDD $(168,169)$ & LPS-injected rats (170) \\
\hline astrocyte & {$\left[{ }^{11}\right.$ C]acetate } & $\mathrm{MCl}, \mathrm{MS}, \mathrm{HC}(171,172)$ & \\
\hline $\mathrm{I}_{2} \mathrm{BS}$ & {$\left[{ }^{11} \mathrm{C}\right] \mathrm{BU} 99008$} & AD, PD, HC (173-178) & Zucker rats, Non-human primates (179-181) \\
\hline
\end{tabular}


TABLE 1 | Continued

\begin{tabular}{lll}
\hline Target & \multicolumn{1}{c}{ Tracer } & Human \\
& {$\left[{ }^{18} \mathrm{~F}\right] \mathrm{FEBU}(\mathrm{BU} 99018)$} & Mice and rats (182) \\
& {$\left[{ }^{11} \mathrm{C}\right] \mathrm{FTIMD}$} & Non-human primates (183) \\
OATP1C1 & {$\left[{ }^{18} \mathrm{~F}\right] 2 \mathrm{~B}-\mathrm{SRF} 101$} & $3 \times \operatorname{Tg}$ mice $(184)$
\end{tabular}

ALS, amyotrophic lateral sclerosis; COX-1/2, cyclooxygenase 1/2; CSF1R, colony stimulating factor 1 receptor; DED, deuterium-L-deprenyl; FTD, Frontotemporal dementia; GBM, glioblastoma; HC, healthy control; iNOS, inducible nitric oxide synthase; I2BS, 12-imidazoline binding sites; LPS, lipopolysaccharides; MCI, mild cognitive impairment; MDD, major depressive disorder; MELAS, mitochondrial myopathy, encephalopathy, lactic acidosis and stroke-like episodes; MMP, matrix metalloproteinases; MS, multiple sclerosis; OATP1C1, organic anion-transporting polypeptide 1C1; ROS, reactive oxygen species; PD, Parkinson's disease; SD, semantic dementia; TREM-1, 2, triggering receptor expressed on myeloid cells 1, 2; TSPO, translocator protein; 6-OHD, 6-hydroxydopamine.

impairment, but not with tau burden assessed by $\left[{ }^{18} \mathrm{~F}\right]$ florbetaben and $\left[{ }^{18} \mathrm{~F}\right] \mathrm{MK}-6240$, respectively, in patients with $\mathrm{AD}$ (74). Whereas Dani et al. showed that $\left[{ }^{11} \mathrm{C}\right] \mathrm{PBR} 28$-measured microglial activation correlates with both tau and $\mathrm{A} \beta$ deposition assessed by $\left[{ }^{18} \mathrm{~F}\right]$ flortaucipir and $\left[{ }^{18} \mathrm{~F}\right]$ flutemetamol in patients with $\mathrm{AD}$ (69) (Figures 2D, E). Studies by Femminell et al. demonstrated an increased regional $\left[{ }^{11} \mathrm{C}\right]$ PBR2 8 binding in patient with MCI, which associated with higher grey matter and hippocampal volume (199). This suggests a potential protective effect of microglia activation in the early stages (199). Hamelin et al. showed a diverging pattern of progression in $\mathrm{AD}$ based on $\left[{ }^{18} \mathrm{~F}\right] \mathrm{DPA}-714$ baseline binding, with a higher baseline associates with less subsequent microglial activation and better cognitive performance in 2-years follow-up (45).

\section{The Third Generation TSPO Tracers}

Several third generations of TSPO tracers $\left[{ }^{18} \mathrm{~F}\right] \mathrm{GE}-180,(\mathrm{R}, \mathrm{S})$ $\left[{ }^{18} \mathrm{~F}\right] \mathrm{GE}-387,\left[{ }^{11} \mathrm{C}\right]$ ER176, $\left[{ }^{11} \mathrm{C}\right] \mathrm{CB} 184,\left[{ }^{11} \mathrm{C}\right] \mathrm{CB} 190,\left[{ }^{11} \mathrm{C}\right] \mathrm{N}^{\prime}$ -MPB, and $\left[{ }^{18} \mathrm{~F}\right] \mathrm{LW} 223$ have been developed $(75,103,105-$ 109). $\left[{ }^{18} \mathrm{~F}\right] \mathrm{GE}-180$ (flutriciclamide), (S)- $\left[{ }^{18} \mathrm{~F}\right] \mathrm{GE}-387$, and $\left[{ }^{11} \mathrm{C}\right]$ ER176 resolve the problem of ligand-dependent attenuation of affinity $(90,97,197)$ in in vitro binding assay where these tracers are insensitive to TSPO $r s 6971$ polymorphisms (104). The $r s 6971$ polymorphisms, however, affects in vivo $\left[{ }^{18} \mathrm{~F}\right] \mathrm{GE}-180$ quantification, revealing lower binding in patients of lowaffinity binders compared to the mixed- and high-affinity binders (88). Several studies have compared the binding properties and performance of second and third generations of TSPO tracers. James et al. found that the detection of microglial activation by using $\left[{ }^{18} \mathrm{~F}\right] \mathrm{GE} 180$ was more sensitive than that by using $\left[{ }^{18} \mathrm{~F}\right]$ PBR06 (94). However, Chaney et al. indicated that $\left[{ }^{11} \mathrm{C}\right] \mathrm{DPA}-713$ PET reflects microglial activation with higher accuracy and sensitivity compared to $\left[{ }^{18} \mathrm{~F}\right] \mathrm{GE}-180$ in a mouse model of stroke (53). Head-to-head comparative PET study by Zanotti-Fregonara et al. showed a more favourable brain entrance property of $\left[{ }^{11} \mathrm{C}\right] \mathrm{PBR} 28$ compared to $\left[{ }^{18} \mathrm{~F}\right] \mathrm{GE}-180$ in human (76). [ $\left.{ }^{11} \mathrm{C}\right] \mathrm{ER} 176$ has demonstrated a higher binding potential and smaller variability compared to $\left[{ }^{11} \mathrm{C}\right] \mathrm{PK} 11195$, $\left[{ }^{11} \mathrm{C}\right]$ PBR28, and $\left[{ }^{11} \mathrm{C}\right] \mathrm{DPA}-713(75,105,106)$. Clinical trial of PET using $\left[{ }^{11} \mathrm{C}\right]$ ER176 for accessing microglia activation in patients with MCI and AD is still ongoing (NCT03744312). Microglial activation assessed by using $\left[{ }^{18} \mathrm{~F}\right] \mathrm{GE}-180$ in different amyloidosis, tauopathy rodent models have been reported (47, 50, 53, 89, 90, 92-102) (Table 1). López-Picón et al. showed that $\left[{ }^{18} \mathrm{~F}\right] \mathrm{GE}-180$ signal reached plateaus at an early stage, while the $\mathrm{A} \beta$ load detected by $\left[{ }^{11} \mathrm{C}\right] \mathrm{PIB}$ was still increasing in APP23 mice (90). A recent study by Sacher et al. showed an asymmetric pattern (hemispheric predominance) of $A \beta$ load $\left(\left[{ }^{18} \mathrm{~F}\right]\right.$ florbetaben) accompanied by microglial activation ( $\left[{ }^{18} \mathrm{~F}\right] \mathrm{GE}$ 180) in App ${ }^{\text {NL-G-F }}$ knock-in mice (96). Increased levels of $\left[{ }^{18} \mathrm{~F}\right]$ GE-180 uptake indicative of microglial activation have been reported in patients with $\mathrm{AD}$, semantic dementia, MCI, and four-repeat tauopathy compared to non-demented controls (8891). Ramakrishnan reported that $\left[{ }^{18} \mathrm{~F}\right] \mathrm{GE}-387$ visualised increased uptake in rat of acute inflammation induced by lipopolysaccharides (LPS) injection and demonstrated sufficient brain uptake in non-human primate (104).

The cellular location of the signal is another major concern for TSPO ligands. Two different binding sites on glial and vascular TSPO were reported for several TSPO ligands, e.g., $\left[{ }^{11} \mathrm{C}\right] \mathrm{PK} 11195$ (57). Ji et al. reported that polymorphisminsensitive ligand $\left[{ }^{18} \mathrm{~F}\right]$ FEBMP (200) yielded a higher contrast to neuroinflammation than $\left[{ }^{11} \mathrm{C}\right] \mathrm{PK} 11195$ in PS19 tauopathy mouse model due to its higher glial-TSPO selectivity (Figures 1F, G) $(57,58)$. Further studies evaluating the TSPO selectivity and insensitivity to TSPO polymorphism of the second and third generations TSPO tracers including $\left[{ }^{18} \mathrm{~F}\right] \mathrm{GE}-180,(\mathrm{~S})$ $\left[{ }^{18} \mathrm{~F}\right] \mathrm{GE}-387$, and $\left[{ }^{11} \mathrm{C}\right] \mathrm{ER} 176$ are highly desired.

\section{Emerging Targets}

Given that TSPO is not exclusively expressed in glia, it is thus imperative to search for new imaging biomarkers that can detect neuroinflammation with higher sensitivity and specificity. Promising targets should have almost exclusive expression in microglia or astrocyte and highly specific ligands to enable in vivo imaging evaluations (32, 170, 201, 202).

\section{Colony-Stimulating Factor 1 Receptor}

CSF1R is expressed mainly on microglia and on infiltrating macrophages/monocytes and dendritic cells in the brain (Figures 1A, B). CSF1R is important for microglia growth, proliferation, and survival. Two endogenous ligands, the growth factors colony stimulating factor-1 and interleukin-34 (203), have been reported for CSF1R. Upregulation in CSF1R have been reported in response to injury and $\mathrm{AD}$-related neuropathology $(204,205)$. Horti et al. developed a new CSF1R tracer $\left[{ }^{11} \mathrm{C}\right] \mathrm{CPPC}$ and captured increased microglial levels of CSF1R in animal models of acute inflammation induced by LPS injection, encephalomyelitis model of multiple sclerosis, and APPsi with cerebral A $\beta$ pathology (124). A recent study from Zhou et al. compared new CSF1R tracers $\left[{ }^{11} \mathrm{C}\right] \mathrm{GW} 2580$ with $\left[{ }^{11} \mathrm{C}\right] \mathrm{CPPC}$ in detecting both acute inflammation induced by LPS injection and chronic inflammation in $\mathrm{APP} \mathrm{PL}^{\mathrm{NL}-\mathrm{G}-\mathrm{F} / \mathrm{NL}-\mathrm{G}-\mathrm{F}}$ knockin mice and showed that $\left[{ }^{11} \mathrm{C}\right] \mathrm{GW} 2580$ captured changes in 
a Mus musculus
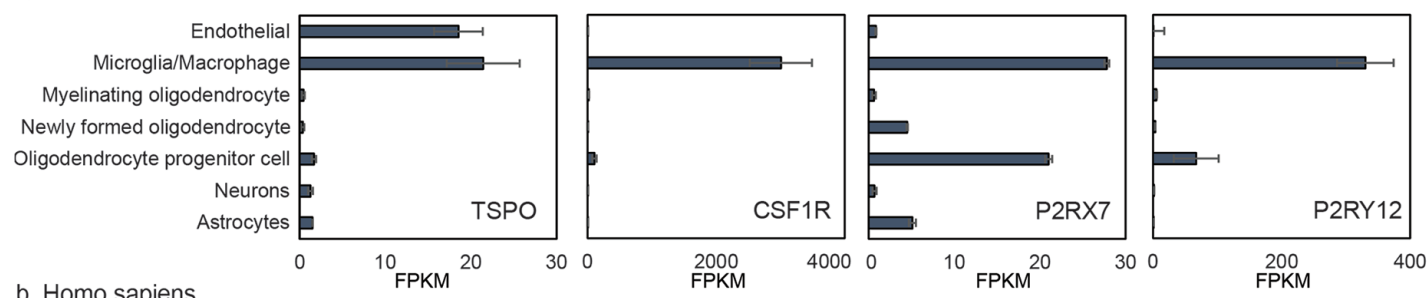

b Homo sapiens
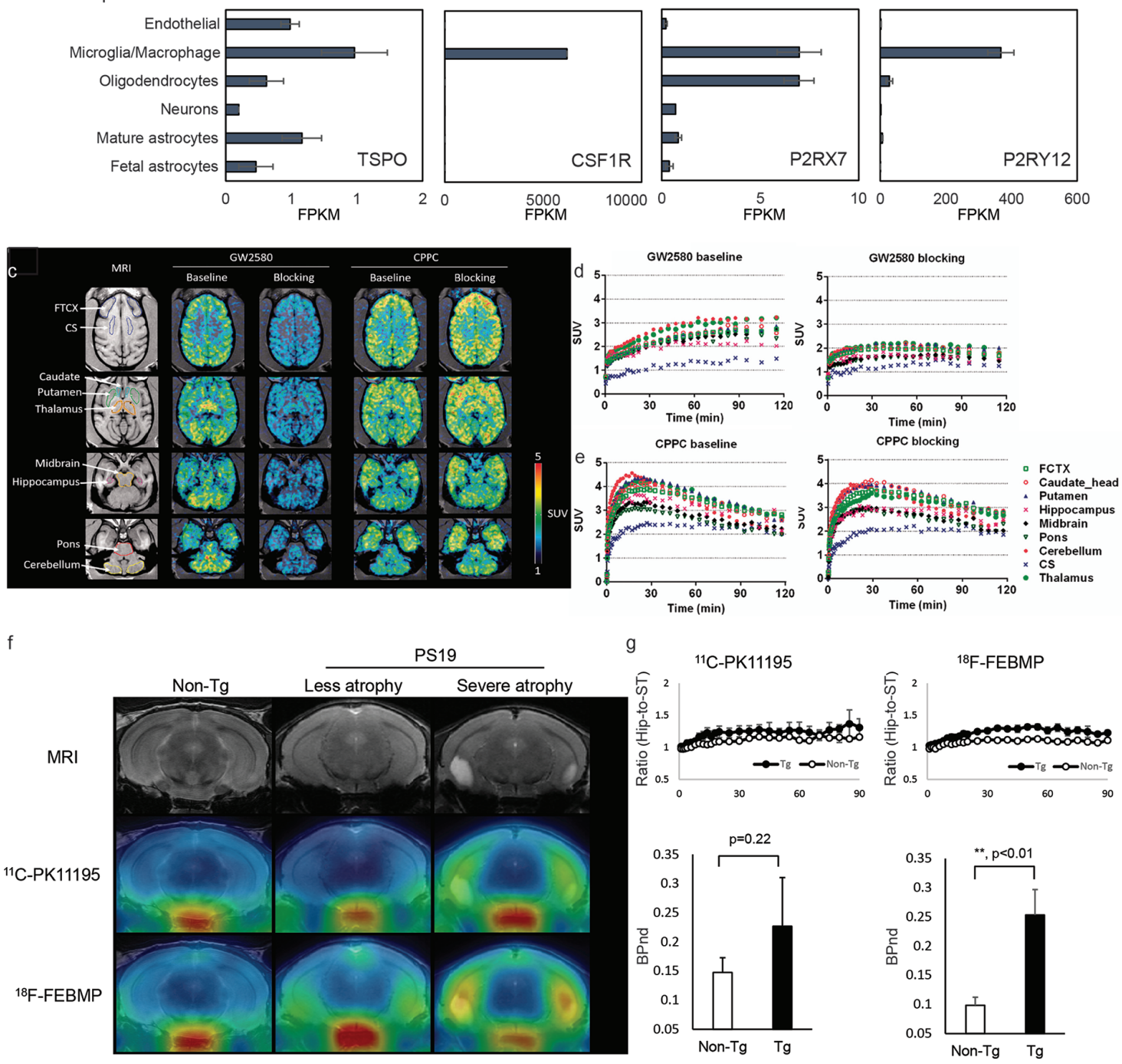

FIGURE 1 | Cellular location of emerging neuroinflammation imaging targets. (A, B) The RNA expression of TSPO, CSF1R, P2RX7, and P2RY12 in mouse (A) and human (B) brain [based on RNA-Seq data $(189,190)]$. FPKM, fragments per kilobase of transcript per million mapped reads. Reproduced from https://www. brainrnaseq.org and $(189,190)$ with permission. (C) Representative transverse planes of $\left[{ }^{11} \mathrm{C}\right] \mathrm{GW} 2580$ and $\left[{ }^{11} \mathrm{C}\right] \mathrm{CPPC}$ SUV $60-120 \mathrm{~min}$ images of a monkey brain superimposed on the monkey's own MR images at baseline and with a homologous blocker treatment. (D, E) Time-radioactivity curves of $\left[{ }^{11} \mathrm{C}\right] \mathrm{GW} 2580$ and $\left[{ }^{11} \mathrm{C}\right]$ CPPC in various brain regions obtained from corresponding PET images. FCTX, frontal cortex; CS, centrium semi-ovale. Reproduced from (64) with permission from Sage Publication. (F, G) Tau lesion-associated microglial TSPO was more sensitively captured by in vivo positron emission tomography $(\mathrm{PET})$ imaging with $\left[{ }^{18} \mathrm{~F}\right]$ FEBMP than $\left[{ }^{11} \mathrm{C}\right]$ PK11195. T2 magnetic resonance imaging (MRI) images and PET images with $\left[{ }^{18} \mathrm{~F}\right.$ FEBMP and $\left[{ }^{11} \mathrm{C}\right] \mathrm{PK} 11195$ in non-transgenic, and PS19 mice with less and severe brain atrophy at 9 months of age (F). Time course of hippocampus (Hip)-to-striatum (ST) ratios of radioactivity and binding potential (BPnd) calculated by simplified reference tissue model with striatum as reference tissue showing significantly increased $\left[{ }^{18} \mathrm{~F}\right] \mathrm{FEBMP}$ but not $\left[{ }^{11} \mathrm{C}\right] \mathrm{PK} 11195$ signal in PS19 compared with non-transgenic mice (G). Reproduced from (57) with permission from Sage Publication. 


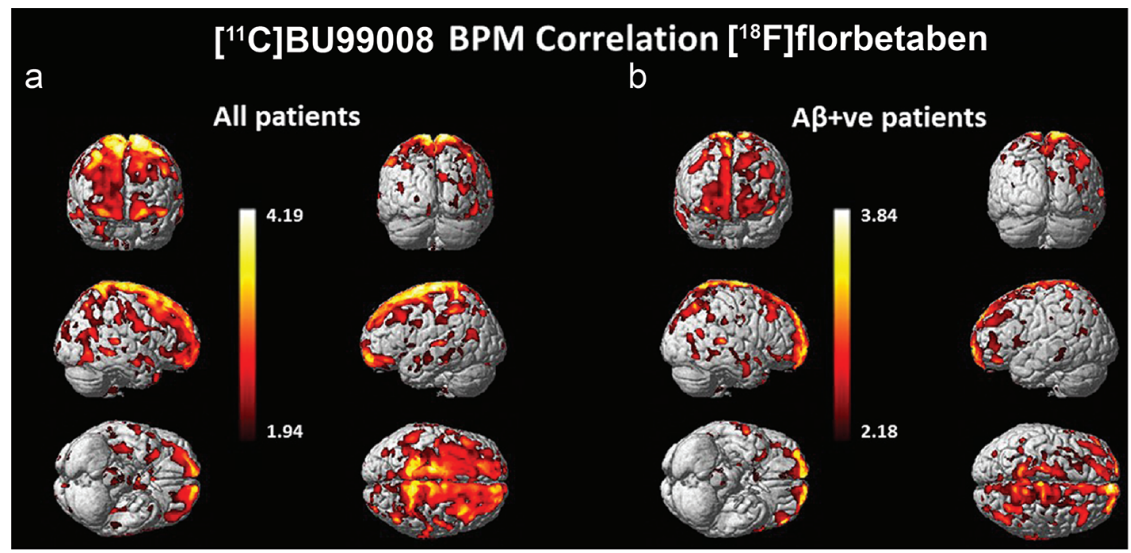

C
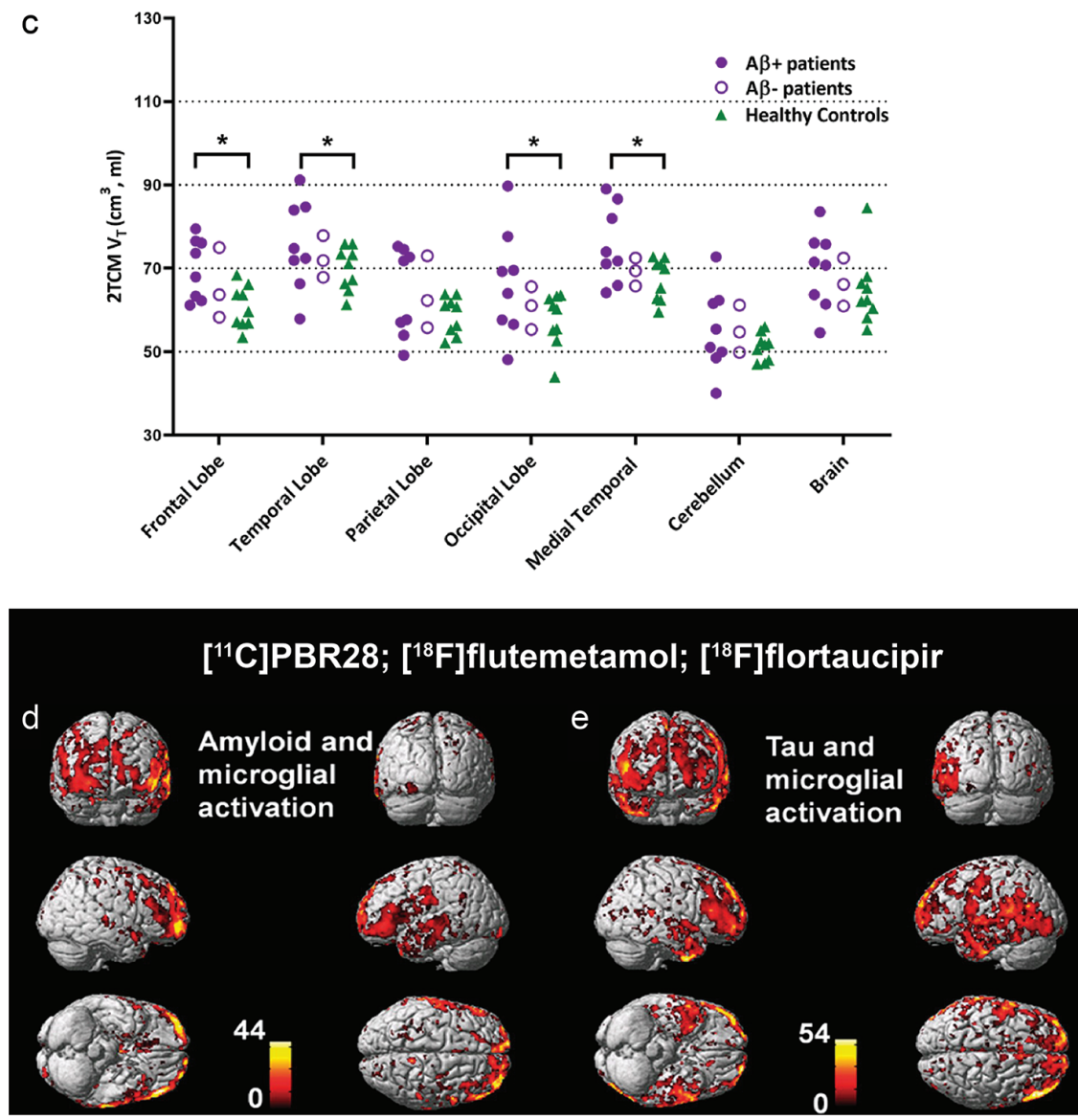

FIGURE 2 | Biological parametric mapping (BPM) correlation between $\left[{ }^{11} \mathrm{C}\right] \mathrm{BU} 99008$ and $\left[{ }^{18} \mathrm{~F}\right]$ florbetaben binding in (A) all cognitively impaired (Cl) subjects and in (B) AB-positive cognitively impaired subjects at a cluster threshold of $p<0.05$ with an extent threshold of 50 voxels. These BPM are T maps describing the strength of the voxel-wise correlations between binding of the two radioligands represented in a common brain space. (C) Dot plot demonstrating the regional $\left[{ }^{11} \mathrm{C}\right] \mathrm{BU} 99008$ total volumes of distribution (Vt) using two-tissue compartmental models in A $\beta$-positive cognitively impaired subjects (purple filled circle), A $\mathrm{A}$-negative $\mathrm{Cl}$ subjects (purple open circle), and healthy controls ( $\mathrm{HC}$, green triangle). "Brain" refers to the composite cortex, combining all the major cortical regions. ${ }^{*} p<0.05$, uncorrected. Reproduced from (176) with permission from Springer Nature. (D, E) Voxel-level correlation between $\left[{ }^{18} \mathrm{C}\right] \mathrm{PBR} 28,\left[{ }^{18} \mathrm{~F}\right] \mathrm{florbetapir}$, and $\left[{ }^{18} \mathrm{~F}\right]$ flutemetamol in the patients with mild cognitive impairment and Alzheimer's disease who were positive for all three tracers. (D) Voxel-level correlations between microglial activation assessed by using $\left[{ }^{18} \mathrm{C}\right]$ PBR28 and tau aggregation assessed by using $\left[{ }^{18} \mathrm{~F}\right]$ florbetapir. (E) Voxel-level correlations between microglial activation assessed by using $\left[{ }^{18} \mathrm{C}\right]$ PBR28 and amyloid deposition assessed by using $\left[{ }^{18} \mathrm{~F}\right]$ flutemetamol. Reproduced from (69) with permission from Oxford University Press. 
CSF1R with higher sensitivity, associated with increased TSPO pattern in the brain (64) (Figures 1C-E).

\section{Cyclooxygenase-1 and Cyclooxygenase-2}

Cyclooxygenase (COX) is an enzyme involved in the production of prostaglandin $\mathrm{H} 2$, which is the substrate for molecules including prostaglandins, prostacyclin, and thromboxanes (206). The two isoforms COX-1 and COX-2 are considered to be involved in the neuroinflammation in neurodegenerative diseases including $\mathrm{AD}$. Immunochemical evidence showed that COX-1 and COX-2 are expressed in microglia and neuron in the central nervous system (207). Several tracers for COX-1 and COX-2 have been developed including $\left[{ }^{18} \mathrm{~F}\right] \mathrm{TMI}(131,208),\left[{ }^{18} \mathrm{~F}\right]$ triacoxib $(209),\left[{ }^{11} \mathrm{C}\right]$ rofecoxib (210), $\left[{ }^{11} \mathrm{C}\right] \mathrm{KTP}-\mathrm{Me}(125,127,211),\left[{ }^{11} \mathrm{C}\right] \mathrm{PS} 13$, and $\left[{ }^{11} \mathrm{C}\right] \mathrm{MC} 1$ $(128,129)$ (Table 1). Ohnishi et al. and Shukuri et al. reported that $\left[{ }^{11} \mathrm{C}\right] \mathrm{KTP}-\mathrm{Me}$ harbours an improved brain-barrier entrance and is highly selective for COX-1 $(125,127,211)$. PET study with $\left[{ }^{11} \mathrm{C}\right]$ KTP-Me showed an increased brain uptake in AD patients compared to healthy controls and in APPswe (Tg2576) mice compared to wild-type mice (125-127): [ $\left.{ }^{11} \mathrm{C}\right] \mathrm{KTP}-\mathrm{Me}$ accumulation was detected in the frontal cortex and hippocampus, in activated microglia surrounding $A \beta$ plaques. Shrestha et al. reported PET imaging of COX-2 ( $\left.\left[{ }^{11} \mathrm{C}\right] \mathrm{MC} 1\right)$ and COX-1 ( $\left.\left[{ }^{11} \mathrm{C}\right] \mathrm{PS} 13\right)$ in monkey brain after LPS-induced neuroinflammation and in human peripheral tissue with inflammation and showed specific detection patterns $(128,129)$.

\section{Cannabinoid Receptor Type 2}

Cannabinoid receptor type $2\left(\mathrm{CB}_{2} \mathrm{R}\right)$ are mainly expressed by immune cells including monocytes, macrophages, and microglia in the brain $(151,152)$ and have low expression levels under physiological conditions $(2,4,31)$. Several classes of tracers for $\mathrm{CB}_{2} \mathrm{R}$ have been developed including $\left[{ }^{11} \mathrm{C}\right]$ methoxy-Sch225336 (212), $\left[{ }^{11} \mathrm{C}\right] \mathrm{NE} 40$ (154), $\left[{ }^{11} \mathrm{C}\right] \mathrm{A}-836339,\left[{ }^{18} \mathrm{~F}\right] 2 \mathrm{f}(149,150),\left[{ }^{18} \mathrm{~F}\right]$ JHU94620 (153), $\left[{ }^{18} \mathrm{~F}\right] \mathrm{RS}-126$, and $\left[{ }^{18} \mathrm{~F}\right]$ RoSMA-18-d6 $(151,152)$ (Table 1). Upregulation of brain $\mathrm{CB}_{2} \mathrm{R}$ expression has been demonstrated in acute inflammation such as LPS-injected model and murine stroke model (151-153) in chronic inflammation senescence-accelerated models (155) and in amyloidosis mouse model associated with $\mathrm{A} \beta$ deposits (150). Ahmad et al. reported lower $\mathrm{CB}_{2} \mathrm{R}$ availability in $\mathrm{A} \beta$-positive $\mathrm{AD}$ patients compared to healthy controls assessed by PET using $\left[{ }^{11} \mathrm{C}\right] \mathrm{NE} 40$ and $\left[{ }^{11} \mathrm{C}\right] \mathrm{PIB}$, respectively. However, no relationship between $\left[{ }^{11} \mathrm{C}\right] \mathrm{NE} 40$ and cerebral A $\beta$ load was observed (154).

\section{Purinergic P2X7 Receptor and P2Y12 Receptor}

The expression of purinergic $\mathrm{P} 2 \mathrm{X} 7$ receptor is found upregulated specifically in M1 microglia. P2X7 receptor mediates NLRP3 inflammasome activation, cytokine and chemokine release, $\mathrm{T}$ lymphocyte survival and differentiation, transcription factor activation, and cell death (213). Microglia monitors and protects neuronal function through purinergic P2Y12 receptor-dependent junctions (214) linked with neuronal mitochondrial activity. Brain injury-induced changes at somatic junctions triggered P2Y12receptor-dependent microglial neuroprotective effect, regulating neuronal calcium load and functional connectivity $(215,216)$. Immunohistochemical staining indicated that the levels of P2Y12 receptor were decreased in the brains derived from patients with multiple sclerosis and $\mathrm{AD}$ cases (217). Several $\mathrm{P} 2 \mathrm{X} 7$ receptor tracers including $\left[{ }^{11} \mathrm{C}\right] \mathrm{GSK} 1482160(110,111),\left[{ }^{11} \mathrm{C}\right] J N J-47965567(\mathrm{~A}-$ 740003) (120), [ $\left.{ }^{18} \mathrm{~F}\right] J N J-64413739$ (112, 114), [ $\left.{ }^{11} \mathrm{C}\right] J \mathrm{NJ}-54173717$ (113), $\left[{ }^{11} \mathrm{C}\right]$ SMW139 (118), and $\left[{ }^{18}\right.$ F]PTTP (218). Janssen et al. showed that $\left[{ }^{11} \mathrm{C}\right]$ SMW139 can detect with high affinity and specificity to the P2X7 receptor by using rAAV3flag-hP2X7R rat model overexpressing human P2X7 receptor (119). Moreover, $\left[{ }^{11} \mathrm{C}\right]$ SMW139 showed higher binding on postmortem brain of $\mathrm{AD}$ patients compared to controls by using in vitro autoradiography studies, corroborating with immunohistochemical staining results (119). One clinical trial is ongoing using $\left[{ }^{11} \mathrm{C}\right]$ SMW139 for imaging neuroinflammation in Parkinson's disease [(PRI-PD) 2018000405-23].

Several P2Y12 receptor probes such as $\left[{ }^{11} \mathrm{C}\right] \mathrm{AZD} 1283,\left[{ }^{11} \mathrm{C}\right]$ $\mathrm{P} 2 \mathrm{Y} 12 \mathrm{R}$-ant, and $\left[{ }^{11} \mathrm{C}\right] 5$ have been developed and evaluated in vivo in animal models $(120,122,123)$. Maeda et al. showed a distinct response of P2Y12 receptor to tau and amyloid deposits using P2Y12 receptor tracer $\left[{ }^{11} \mathrm{C}\right] \mathrm{AZD} 1283$. The levels of $\mathrm{P} 2 \mathrm{Y} 12$ receptor decline in tau-laden region with increased total level of microglia in rTg4510 and PS19 tau mice and increase in APP23 and APP ${ }^{\text {NL-F/NL-F }}$ mice (123). However PET imaging using $\left[{ }^{11} \mathrm{C}\right] \mathrm{AZD} 1283$ showed no uptake signal in the wild-type mouse brain. Two other tracers $\left[{ }^{11} \mathrm{C}\right]$ P2Y12R-ant and $\left[{ }^{11} \mathrm{C}\right] 5$ have showed sufficient brain uptake and promising results in experimental autoimmune encephalomyelitis model of multiple sclerosis (120) and stroke model for detecting antiinflammatory microglia (122).

\section{Astroglia Imaging MAO-B}

Irreversible MAO-B inhibitors $\left[{ }^{11} \mathrm{C}\right]$ deuterium-L-deprenyl (DED) have been used in PET imaging studies and demonstrated early astrocytosis in sporadic and autosomal dominant $\mathrm{AD}$ patients $(61,156-161,163)$ and in amyloidosis mouse models $(163,164)$. $\left[{ }^{18} \mathrm{~F}\right]$ fluorodeprenyl- $\mathrm{D}_{2}$ showed favorable kinetic properties with relatively fast washout from non-human primate brain and improved sensitivity for MAO-B imaging (165). However, the technical challenges of irreversible inhibitors such as deprenyl hinder the accurate image analysis. Several reversible-binding inhibitors have been developed in recent years such as $\left[{ }^{11} \mathrm{C}\right] \mathrm{Cou}$ (170, 219), $\left[{ }^{11} \mathrm{C}\right]$ SL25.1188 (168), and $\left[{ }^{11} \mathrm{C}\right]$ SMBT-1 (166). Harada et al. showed a specific increased regional retention of $\left[{ }^{11} \mathrm{C}\right] \mathrm{SMBT}-1$ in the cortical and hippocampal regions in patients with $\mathrm{AD}$ compared to healthy controls (166).

\section{$\mathrm{I}_{2} \mathrm{BS}$}

$\mathrm{I}_{2} \mathrm{BS}$ that locates on both monoamine oxidases $\mathrm{A}$ (MAO-A) and $\mathrm{B}$ (MAO-B) is another emerging target for astrocytosis imaging $(173-175,220)$. $\left[{ }^{11} \mathrm{C}\right]$ FTIMD shows the specific-binging to $\mathrm{I}_{2} \mathrm{BS}$ as shown by PET and autoradiography in the monkey brain (183). Wilson et al. demonstrated reactive astroglia detected by using $\left[{ }^{11} \mathrm{C}\right]$ BU99008 PET early in Parkinson's disease in response to $\alpha$ synuclein accumulation (174). Recent postmortem binding and autoradiography study by Kumar et al. showed increased level of $\left[{ }^{3} \mathrm{H}\right]$ BU99008 binding in postmortem brain tissue from patients with AD compared to healthy controls $(173,221)$. Calsolaro et al. recently demonstrated increased cortical astrocytosis assessed by 
$\left[{ }^{11} \mathrm{C}\right] \mathrm{BU} 99008$ with high cerebral $\mathrm{A} \beta$ load assessed by $\left[{ }^{18} \mathrm{~F}\right]$ florbetaben in patients with $\mathrm{MCI}$ and $\mathrm{AD}$ (176) (Figures 2AC). Livingston et al. demonstrated that increased astrocytosis assessed by $\left[{ }^{11} \mathrm{C}\right] \mathrm{BU} 99008$ in regions of earlier stages with low $\mathrm{A} \beta$ loads assessed by $\left[{ }^{18} \mathrm{~F}\right]$ florbetaben and reduced astrocytosis in regions of advanced stage with greater $\mathrm{A} \beta$ load and atrophy (177). In vitro autoradiography and immune-histochemical staining showed the specificity of $\left[{ }^{3} \mathrm{H}\right] \mathrm{BU} 99008$ and the colocalization of with glial fibrillary acidic protein staining of astroctyes in brain tissues from patients with $\mathrm{AD}$.

\section{DISCUSSION}

Non-invasive detection of central pathologies is indispensable for understanding the mechanism underlying $\mathrm{AD}$ continuum and for facilitating early and differential diagnosis $(28,222-225)$. TSPOPET is still the most powerful imaging tool for AD-associated neuroinflammation but is currently facing two challenges. First, a human TSPO polymorphism TSPO rs6971 commonly affects the binding affinities of the second generation tracers to a different extent. Classification with polymorphism enables to correct the variability and bias from different binding affinities, but it raises the threshold for sample size of human subjects. Third-generation tracers have been developed for circumventing this limitation. In vitro testing in post-mortem human brain tissues have demonstrated the insensitivity of $\left[{ }^{11} \mathrm{C}\right] \mathrm{GE}-180,\left[{ }^{11} \mathrm{C}\right] \mathrm{GE}-387$, and $\left[{ }^{11} \mathrm{C}\right]$ ER176 to TSPO polymorphism $(75,106,197)$. However, recent clinical study with $\left[{ }^{11} \mathrm{C}\right]$ ER176 $(105)$ and $\left[{ }^{11} \mathrm{C}\right] \mathrm{GE}-180(88)$ demonstrated a significant decrease in ligand retention in lowaffinity binders, suggesting the necessity of further in vivo examination. Second, the heterogenous cellular sources of TSPO PET tracers have been demonstrated in astrocytes, endothelial cells, and vascular smooth muscle cells, in addition to microglia in both patients with AD and animal models $(61,85,86,193,226-229)$ (Figures 1A, B). Although conventional opinions consider microglia as major cellular source of TSPO in the central nervous system, latest study finds vascular TSPO provides major binding sites for TSPO ligands including most widely used $\left[{ }^{11} \mathrm{C}\right] \mathrm{PK} 11195$ and $\left[{ }^{11} \mathrm{C}\right]$ PBR28 in normal mouse brains (57). These findings suggest the possibility that changes in TSPO PET signal may be partly due to changes in the levels of vascular TSPO and not purely of glial TSPO. $\left[{ }^{18} \mathrm{~F}\right] \mathrm{FEBMP}$ and $\left[{ }^{11} \mathrm{C}\right] \mathrm{AC}-5216$ showed relatively selectivity for glial-TSPO compared to other ligands such as $\left[{ }^{11} \mathrm{C}\right]$ PK11195 (200). It remains to be investigated whether the third generation of TSPO tracers shows a portion of vascular TSPO detection similarly. Moreover, further research on next generations of TSPO tracers are needed, with the selection criteria including optimal binding property, insensitivity for TSPO polymorphism, and high glial TSPO selectivity.

The role of neuroinflammation in $\mathrm{AD}$ pathogenesis is still not fully elucidated. Early clinical studies with first generation tracer $\left[{ }^{11} \mathrm{C}\right] \mathrm{PK} 11195$ showed conflicting results in the brains from AD patients. Some studies demonstrated significant increases in $\left[{ }^{11} \mathrm{C}\right]$ PK11195 retention in diseased brain regions in $\mathrm{AD}(230,231)$, which was not observed in some other studies $(232,233)$. Albrecht et al. recently reported negative associations between regional $\mathrm{A} \beta$ and tau PET uptake and CSF inflammatory markers in patients with $\mathrm{AD}$ and in non-demented controls and suggested a protective role of neuroinflammation (234). Ewers et al. showed that a higher CSF level of soluble TREM2 is indicative of microglia activation in patients with AD. The CSF level of TREM2 negatively aassociated with the rate of $A \beta$ accumulation assessed by using $\left[{ }^{18} \mathrm{~F}\right]$ florbetapir over 2-years follow-up in AD patients (101). Biphasic trajectory with an early increase and a later decline in the level of microglial activation might explain such inconsistency between results from clinical studies (62). The recently reported biphasic trajectory of astrocytosis (177) adds further complexity in the interpretation.

A recent study has showed that microglia is involved in the formation of senile plaque by promoting the diffuse form converting to dense cored form (15). In vitro immunohistochemical analysis found that TSPO-positive microglia were surrounded dense cored plaque, not diffuse plaques (235). These results may explain the complex spatial association between TSPO-PET and amyloid-PET signals. $\left[{ }^{11} \mathrm{C}\right]$ PBR28 signal correlated with both tau aggregation and $A \beta$ deposition (55), suggesting distinct dynamic profiles of microglial activation. Collectively, current clinical studies have not provided a consensus on association between TSPO-associated neuroinflammation and $\mathrm{AD}$-pathological changes. Given the different binding sites in glial and vascular TSPO for different tracers, the divergent results using different TSPO-PET tracers are not unexpected. A multitracer imaging paradigm for detecting the regional patterns of $A \beta$, tau, and microglia activation and astrocytosis is expected to provide better temporal and spatia mapping of disease processes and assessment of immunomodulatory therapeutic interventions in clinical study.

Several promising targets and tracers for neuroinflammation imaging have been reported but not yet been evaluated in $A D$ patients or animal models, such as the ligands for inducible nitric oxide synthase $\left(\left[{ }^{18} \mathrm{~F}\right] \mathrm{FBAT}\right)$, reactive oxygen species $\left(\left[{ }^{18} \mathrm{~F}\right]\right.$ ROStrace $\left[{ }^{18} \mathrm{~F}\right]$ ox-ROStrace, $\left[{ }^{18} \mathrm{~F}\right]$ dihydromethidine, $\left[{ }^{11} \mathrm{C}\right]$ Ascorbic. $\left[{ }^{62} \mathrm{Cu}\right]$ ATSM, $\left[{ }^{11} \mathrm{C}\right]$ dehydroascorbic acid) $(132-137)$, TREM-1 ( $\left[{ }^{64} \mathrm{Cu}\right]$ TREM1-mAb), matrix metalloproteinases $\left(\left[{ }^{18} \mathrm{~F}\right]\right.$ BR-351, $\left.\left[{ }^{18} \mathrm{~F}\right] \mathrm{BR}-420\right)(144-146)$, astrocyte metabolism $\left(\left[{ }^{11} \mathrm{C}\right]\right.$ acetate) $(171,172), \mathrm{I}_{2} \mathrm{BS}\left(\left[{ }^{8} \mathrm{~F}\right] \mathrm{FEBU}\right)(182)$, and organic aniontransporting polypeptide $1 \mathrm{C} 1\left(\left[{ }^{18} \mathrm{~F}\right] 2 \mathrm{~B}-\mathrm{SRF} 101\right)$ (184). More preclinical and clinical evidence are required to indicate the utilities of these emerging ligands in in vivo imaging. An almost exclusive expression of CSF1R and P2X7 receptor and P2Y12 receptor in microglia have demonstrated their potentials as nextgeneration imaging targets for microglia activation. Further evaluation of these tracers in amyloidosis and tauopathy models and patients with $\mathrm{MCI}$ and $\mathrm{AD}$ will potentially facilitate better phenotyping of microglia activation. The association of these emerging targets with $\mathrm{AD}$ pathologies, disease progression, and the improvement in the ligand binding properties and analysis methods for PET data require further investigations (236). With the advances in new techniques, e.g., single-cell analysis of neuroinflammatory responses and plasma biomarkers, the link between neuroinflammation PET with other indicators will likely be studied in a more systematic manner. 


\section{AUTHOR CONTRIBUTIONS}

$\mathrm{RZ}, \mathrm{BJ}$, and $\mathrm{RN}$ wrote the first draft and prepared the figures. All authors contributed to the article and approved the submitted version.

\section{REFERENCES}

1. Leng F, Edison P. Neuroinflammation and Microglial Activation in Alzheimer Disease: Where do We Go From Here? Nat Rev Neurol (2021) 17(3):157-72. doi: 10.1038/s41582-020-00435-y

2. Ransohoff RM. How Neuroinflammation Contributes to Neurodegeneration. Science (2016) 353(6301):777. doi: 10.1126/science. aag 2590

3. Allen NJ, Lyons DA. Glia as Architects of Central Nervous System Formation and Function. Science (2018) 362(6411):181-5. doi: 10.1126/ science.aat 0473

4. Heneka MT, Carson MJ, El Khoury J, Landreth GE, Brosseron F, Feinstein DL, et al. Neuroinflammation in Alzheimer's Disease. Lancet Neurol (2015) 14(4):388-405. doi: 10.1016/s1474-4422(15)70016-5

5. Hickman S, Izzy S, Sen P, Morsett L, El Khoury J. Microglia in Neurodegeneration. Nat Neurosci (2018) 21(10):1359-69. doi: 10.1038/ s41593-018-0242-x

6. Grubman A, Choo XY, Chew G, Ouyang JF, Sun G, Croft NP, et al. Transcriptional Signature in Microglia Associated With A $\beta$ Plaque Phagocytosis. Nat Commun (2021) 12(1):3015. doi: 10.1038/s41467-02123111-1

7. Salter MW, Stevens B. Microglia Emerge as Central Players in Brain Disease. Nat Med (2017) 23(9):1018-27. doi: 10.1038/nm.4397

8. Mathys H, Adaikkan C, Gao F, Young JZ, Manet E, Hemberg M, et al. Temporal Tracking of Microglia Activation in Neurodegeneration at SingleCell Resolution. Cell Rep (2017) 21(2):366-80. doi: 10.1016/j.celrep. 2017.09.039

9. Friedman BA, Srinivasan K, Ayalon G, Meilandt WJ, Lin H, Huntley MA, et al. Diverse Brain Myeloid Expression Profiles Reveal Distinct Microglial Activation States and Aspects of Alzheimer's Disease Not Evident in Mouse Models. Cell Rep (2018) 22(3):832-47. doi: 10.1016/j.celrep.2017.12.066

10. Deczkowska A, Keren-Shaul H, Weiner A, Colonna M, Schwartz M, Amit I. Disease-Associated Microglia: A Universal Immune Sensor of Neurodegeneration. Cell (2018) 173(5):1073-81. doi: 10.1016/j.cell.2018. 05.003

11. Keren-Shaul H, Spinrad A, Weiner A, Matcovitch-Natan O, Dvir-Szternfeld R, Ulland TK, et al. A Unique Microglia Type Associated With Restricting Development of Alzheimer's Disease. Cell (2017) 169(7):1276-90.e17. doi: 10.1016/j.cell.2017.05.018

12. Song WM, Colonna M. The Identity and Function of Microglia in Neurodegeneration. Nat Immunol (2018) 19(10):1048-58. doi: 10.1038/ s41590-018-0212-1

13. Leng K, Li E, Eser R, Piergies A, Sit R, Tan M, et al. Molecular Characterization of Selectively Vulnerable Neurons in Alzheimer's Disease. Nat Neurosci (2021) 24(2):276-87. doi: 10.1038/s41593-020-00764-7

14. Parhizkar S, Arzberger T, Brendel M, Kleinberger G, Deussing M, Focke C, et al. Loss of TREM2 Function Increases Amyloid Seeding But Reduces Plaque-Associated ApoE. Nat Neurosci (2019) 22(2):191-204. doi: 10.1038/ s41593-018-0296-9

15. Huang Y, Happonen KE, Burrola PG, O’Connor C, Hah N, Huang L, et al. Microglia Use TAM Receptors to Detect and Engulf Amyloid $\beta$ Plaques. Nat Immunol (2021) 22(5):586-94. doi: 10.1038/s41590-021-00913-5

16. Liddelow SA, Guttenplan KA, Clarke LE, Bennett FC, Bohlen CJ, Schirmer L, et al. Neurotoxic Reactive Astrocytes are Induced by Activated Microglia. Nature (2017) 541(7638):481-7. doi: 10.1038/nature21029

17. Li T, Liu T, Chen X, Li L, Feng M, Zhang Y, et al. Microglia Induce the Transformation of A1/A2 Reactive Astrocytes via the CXCR7/PI3K/Akt Pathway in Chronic Post-Surgical Pain. J Neuroinflamm (2020) 17(1):211. doi: 10.1186/s12974-020-01891-5

\section{FUNDING}

RN acknowledged the funding by Helmut Horten Stiftung, Vontobel Stiftung, UZH Entrepreneur Fellowship (reference no. MEDEF-20-021).

18. Escartin C, Galea E, Lakatos A, O’Callaghan JP, Petzold GC, Serrano-Pozo A, et al. Reactive Astrocyte Nomenclature, Definitions, and Future Directions. Nat Neurosci (2021) 24(3):312-25. doi: 10.1038/s41593-020 00783-4

19. Clarke LE, Liddelow SA, Chakraborty C, Münch AE, Heiman M, Barres BA Normal Aging Induces A1-Like Astrocyte Reactivity. Proc Natl Acad Sci (2018) 115(8):E1896. doi: 10.1073/pnas.1800165115

20. Chun H, Im H, Kang YJ, Kim Y, Shin JH, Won W, et al. Severe Reactive Astrocytes Precipitate Pathological Hallmarks of Alzheimer's Disease via $\mathrm{H}$ (2)O(2)(-) Production. Nat Neurosci (2020) 23(12):1555-66. doi: 10.1038/ s41593-020-00735-y

21. Kovacs GG, Ferrer I, Grinberg LT, Alafuzoff I, Attems J, Budka H, et al Aging-Related Tau Astrogliopathy (ARTAG): Harmonized Evaluation Strategy. Acta Neuropathol (2016) 131(1):87-102. doi: 10.1007/s00401015-1509-x

22. Habib N, McCabe C, Medina S, Varshavsky M, Kitsberg D, Dvir-Szternfeld $\mathrm{R}$, et al. Disease-Associated Astrocytes in Alzheimer's Disease and Aging. Nat Neurosci (2020) 23(6):701-6. doi: 10.1038/s41593-020-0624-8

23. Elahi FM, Casaletto KB, La Joie R, Walters SM, Harvey D, Wolf A, et al Plasma Biomarkers of Astrocytic and Neuronal Dysfunction in Early- and Late-Onset Alzheimer's Disease. Alzheimers Dement (2020) 16(4):681-95 doi: 10.1016/j.jalz.2019.09.004

24. Chatterjee P, Pedrini S, Stoops E, Goozee K, Villemagne VL, Asih PR, et al Plasma Glial Fibrillary Acidic Protein is Elevated in Cognitively Normal Older Adults at Risk of Alzheimer's Disease. Trans Psychiatry (2021) 11 (1):27. doi: 10.1038/s41398-020-01137-1

25. Verberk IMW, Thijssen E, Koelewijn J, Mauroo K, Vanbrabant J, de Wilde A, et al. Combination of Plasma Amyloid Beta((1-42/1-40)) and Glial Fibrillary Acidic Protein Strongly Associates With Cerebral Amyloid Pathology. Alzheimers Res Ther (2020) 12(1):118. doi: 10.1186/s13195020-00682-7

26. Ishikawa A, Tokunaga M, Maeda J, Minamihisamatsu T, Shimojo M Takuwa $\mathrm{H}$, et al. In Vivo Visualization of Tau Accumulation, Microglia Activation, and Brain Atrophy in a Mouse Model of Tauopathy Rtg4510. J Alzheimers Dis (2018) 61(3):1037-52. doi: 10.3233/jad-170509

27. Ni R, Ji B, Ono M, Sahara N, Zhang MR, Aoki I, et al. Comparative in-Vitro and in-Vivo Quantifications of Pathological Tau Deposits and Their Association With Neurodegeneration in Tauopathy Mouse Models. J Nucl Med (2018) 59(6):960-6. doi: 10.2967/jnumed.117.201632

28. Villemagne VL, Dore V, Burnham SC, Masters CL, Rowe CC. Imaging Tau and Amyloid-Beta Proteinopathies in Alzheimer Disease and Other Conditions. Nat Rev Neurol (2018) 14(4):225-36. doi: 10.1038/ nrneurol.2018.9

29. Tagai K, Ono M, Kubota M, Kitamura S, Takahata K, Seki C, et al. HighContrast In Vivo Imaging of Tau Pathologies in Alzheimer's and NonAlzheimer's Disease Tauopathies. Neuron (2021) 109(1):42-58.e8 doi: 10.1016/j.neuron.2020.09.042

30. Dubois B, Villain N, Frisoni GB, Rabinovici GD, Sabbagh M, Cappa S, et al Clinical Diagnosis of Alzheimer's Disease: Recommendations of the International Working Group. Lancet Neurol (2021) 20(6):484-96 doi: 10.1016/S1474-4422(21)00066-1

31. Razansky D, Klohs J, Ni R. Multi-Scale Optoacoustic Molecular Imaging of Brain Diseases. Eur J Nucl Med Mol Imaging (2021). doi: 10.1007/s00259021-05207-4

32. Kreisl WC, Kim MJ, Coughlin JM, Henter ID, Owen DR, Innis RB. PET Imaging of Neuroinflammation in Neurological Disorders. Lancet Neurol (2020) 19(11):940-50. doi: 10.1016/s1474-4422(20)30346-x

33. Ni R, Dean-Ben XL, Kirschenbaum D, Rudin M, Chen Z, Crimi A, et al Whole Brain Optoacoustic Tomography Reveals Strain-Specific Regiona 
Beta-Amyloid Densities in Alzheimer's Disease Amyloidosis Models. bioRxiv (2020). doi: 10.1101/2020.02.25.964064

34. Ni R, Rudin M, Klohs J. Cortical Hypoperfusion and Reduced Cerebral Metabolic Rate of Oxygen in the Arcabeta Mouse Model of Alzheimer's Disease. Photoacoustics (2018) 10:38-47. doi: 10.1016/j.pacs.2018.04.001

35. Ono M, Sahara N, Kumata K, Ji B, Ni RQ, Koga S, et al. Distinct Binding of PET Ligands PBB3 and AV-1451 to Tau Fibril Strains in Neurodegenerative Tauopathies. Brain (2017) 140:764-80. doi: 10.1093/brain/aww339

36. Luzi F, Savickas V, Taddei C, Hader S, Singh N, Gee AD, et al. Radiolabeling of [(11)C]FPS-ZM1, a Receptor for Advanced Glycation End ProductsTargeting Positron Emission Tomography Radiotracer, Using a [(11)C]CO (2)-To-[(11)C]CO Chemical Conversion. Future Med Chem (2020) 12 (6):511-21. doi: 10.4155/fmc-2019-0329

37. Parbo P, Ismail R, Hansen KV, Amidi A, Mårup FH, Gottrup H, et al. Brain Inflammation Accompanies Amyloid in the Majority of Mild Cognitive Impairment Cases Due to Alzheimer's Disease. Brain (2017) 140(7):200211. doi: 10.1093/brain/awx120

38. Malpetti M, Kievit RA, Passamonti L, Jones PS, Tsvetanov KA, Rittman T, et al. Microglial Activation and Tau Burden Predict Cognitive Decline in Alzheimer's Disease. Brain (2020) 143(5):1588-602. doi: 10.1093/brain/ awaa088

39. Nicastro N, Malpetti M, Mak E, Williams GB, Bevan-Jones WR, Carter SF, et al. Gray Matter Changes Related to Microglial Activation in Alzheimer's Disease. Neurobiol Aging (2020) 94:236-42. doi: 10.1016/j.neurobiolaging.2020.06.010

40. Fan Z, Brooks DJ, Okello A, Edison P. An Early and Late Peak in Microglial Activation in Alzheimer's Disease Trajectory. Brain J Neurol (2017) 140 (3):792-803. doi: 10.1093/brain/aww349

41. Ismail R, Parbo P, Madsen LS, Hansen AK, Hansen KV, Schaldemose JL, et al. The Relationships Between Neuroinflammation, Beta-Amyloid and Tau Deposition in Alzheimer's Disease: A Longitudinal PET Study. J Neuroinflamm (2020) 17(1):151. doi: 10.1186/s12974-020-01820-6

42. Su L, Surendranathan A, Huang Y, Bevan-Jones WR, Passamonti L, Hong YT, et al. Relationship Between Tau, Neuroinflammation and Atrophy in Alzheimer's Disease: The NIMROD Study. Inf Fusion (2021) 67:116-24. doi: 10.1016/j.inffus.2020.10.006

43. Passamonti L, Rodríguez PV, Hong YT, Allinson KSJ, Bevan-Jones WR, Williamson D, et al. [11c]PK11195 Binding in Alzheimer Disease and Progressive Supranuclear Palsy. Neurology (2018) 90(22):e1989. doi: 10.1212/WNL.0000000000005610

44. Chiquita S, Ribeiro M, Castelhano J, Oliveira F, Sereno J, Batista M, et al. A Longitudinal Multimodal In Vivo Molecular Imaging Study of the 3xtg-AD Mouse Model Shows Progressive Early Hippocampal and Taurine Loss. Hum Mol Genet (2019) 28(13):2174-88. doi: 10.1093/hmg/ddz045

45. Hamelin L, Lagarde J, Dorothée G, Potier MC, Corlier F, Kuhnast B, et al. Distinct Dynamic Profiles of Microglial Activation Are Associated With Progression of Alzheimer's Disease. Brain (2018) 141(6):1855-70. doi: 10.1093/brain/awy079

46. Hagens MHJ, Golla SV, Wijburg MT, Yaqub M, Heijtel D, Steenwijk MD, et al. In Vivo Assessment of Neuroinflammation in Progressive Multiple Sclerosis: A Proof of Concept Study With [(18)F]DPA714 PET. J Neuroinflamm (2018) 15(1):314. doi: 10.1186/s12974-018-1352-9

47. Hu W, Pan D, Wang Y, Bao W, Zuo C, Guan Y, et al. PET Imaging for Dynamically Monitoring Neuroinflammation in APP/PS1 Mouse Model Using [(18)F]Dpa714. Front Neurosci (2020) 14:810. doi: 10.3389/ fnins.2020.00810

48. Chaney A, Bauer M, Bochicchio D, Smigova A, Kassiou M, Davies KE, et al. Longitudinal Investigation of Neuroinflammation and Metabolite Profiles in the APP(swe) $\times \operatorname{Ps} 1(\Delta \mathrm{e} 9)$ Transgenic Mouse Model of Alzheimer's Disease. J Neurochem (2018) 144(3):318-35. doi: 10.1111/jnc.14251

49. Sérrière S, Tauber C, Vercouillie J, Mothes C, Pruckner C, Guilloteau D, et al. Amyloid Load and Translocator Protein $18 \mathrm{kDa}$ in APPswePS1-De9 Mice: A Longitudinal Study. Neurobiol Aging (2015) 36(4):1639-52. doi: 10.1016/ j.neurobiolaging.2014.11.023

50. Chaney AM, Lopez-Picon FR, Serrière S, Wang R, Bochicchio D, Webb SD, et al. Prodromal Neuroinflammatory, Cholinergic and Metabolite Dysfunction Detected by PET and MRS in the TgF344-AD Transgenic Rat Model of AD: A Collaborative Multi-Modal Study. Theranostics (2021) 11(14):6644-67. doi: 10.7150/thno.56059
51. Takkinen JS, López-Picón FR, Al Majidi R, Eskola O, Krzyczmonik A, Keller T, et al. Brain Energy Metabolism and Neuroinflammation in Ageing APP/ PS1-21 Mice Using Longitudinal (18)F-FDG and (18)F-DPA-714 PET Imaging. J Cereb Blood Flow Metab (2017) 37(8):2870-82. doi: 10.1177/ $0271678 \times 16677990$

52. Yokokura M, Terada T, Bunai T, Nakaizumi K, Takebayashi K, Iwata Y, et al. Depiction of Microglial Activation in Aging and Dementia: Positron Emission Tomography With [(11)C]DPA713 Versus [(11)C](R)Pk11195. J Cereb Blood Flow Metab (2017) 37(3):877-89. doi: 10.1177/ 0271678x16646788

53. Chaney A, Cropper HC, Johnson EM, Lechtenberg KJ, Peterson TC, Stevens MY, et al. (11)C-DPA-713 Versus (18)F-GE-180: A Preclinical Comparison of Translocator Protein $18 \mathrm{kDa}$ PET Tracers to Visualize Acute and Chronic Neuroinflammation in a Mouse Model of Ischemic Stroke. J Nucl Med (2019) 60(1):122-8. doi: 10.2967/jnumed.118.209155

54. Tsukada H, Nishiyama S, Ohba H, Kanazawa M, Kakiuchi T, Harada N. Comparing Amyloid- $\beta$ Deposition, Neuroinflammation, Glucose Metabolism, and Mitochondrial Complex I Activity in Brain: A PET Study in Aged Monkeys. Eur J Nucl Med Mol Imaging (2014) 41 (11):2127-36. doi: 10.1007/s00259-014-2821-8

55. Keller T, López-Picón FR, Krzyczmonik A, Forsback S, Takkinen JS, Rajander J, et al. Comparison of High and Low Molar Activity TSPO Tracer [(18)F]F-DPA in a Mouse Model of Alzheimer's Disease. J Cereb Blood Flow Metab (2020) 40(5):1012-20. doi: 10.1177/0271678x19853117

56. Fairley LH, Sahara N, Aoki I, Ji B, Suhara T, Higuchi M, et al. Neuroprotective Effect of Mitochondrial Translocator Protein Ligand in a Mouse Model of Tauopathy. J Neuroinflamm (2021) 18(1):76. doi: 10.1186/ s12974-021-02122-1

57. Ji B, Ono M, Yamasaki T, Fujinaga M, Zhang MR, Seki C, et al. Detection of Alzheimer's Disease-Related Neuroinflammation by a PET Ligand Selective for Glial Versus Vascular Translocator Protein. J Cereb Blood Flow Metab (2021) 41(8):2076-89. doi: 10.1177/0271678x21992457

58. Barron AM, Ji B, Fujinaga M, Zhang MR, Suhara T, Sahara N, et al. In Vivo Positron Emission Tomography Imaging of Mitochondrial Abnormalities in a Mouse Model of Tauopathy. Neurobiol Aging (2020) 94:140-8. doi: 10.1016/j.neurobiolaging.2020.05.003

59. Ji B, Maeda J, Sawada M, Ono M, Okauchi T, Inaji M, et al. Imaging of Peripheral Benzodiazepine Receptor Expression as Biomarkers of Detrimental Versus Beneficial Glial Responses in Mouse Models of Alzheimer's and Other CNS Pathologies. J Neurosci (2008) 28(47):1225567. doi: $10.1523 /$ jneurosci.2312-08.2008

60. Maeda J, Zhang MR, Okauchi T, Ji B, Ono M, Hattori S, et al. In Vivo Positron Emission Tomographic Imaging of Glial Responses to AmyloidBeta and Tau Pathologies in Mouse Models of Alzheimer's Disease and Related Disorders. J Neurosci (2011) 31(12):4720-30. doi: 10.1523/ jneurosci.3076-10.2011

61. Ni R, Röjdner J, Voytenko L, Dyrks T, Thiele A, Marutle A, et al. In Vitro Characterization of the Regional Binding Distribution of Amyloid PET Tracer Florbetaben and the Glia Tracers Deprenyl and PK1195 in Autopsy Alzheimer's Brain Tissue. J Alzheimer's Dis (2021) 80(4):1723-37. doi: 10.3233/JAD-201344

62. Varrone A, Oikonen V, Forsberg A, Joutsa J, Takano A, Solin O, et al. Positron Emission Tomography Imaging of the 18 -kDa Translocator Protein (TSPO) With [18F]FEMPA in Alzheimer's Disease Patients and Control Subjects. Eur J Nucl Med Mol Imaging (2015) 42(3):438-46. doi: 10.1007/ s00259-014-2955-8

63. Miyoshi M, Ito $\mathrm{H}$, Arakawa R, Takahashi $\mathrm{H}$, Takano H, Higuchi M, et al. Quantitative Analysis of Peripheral Benzodiazepine Receptor in the Human Brain Using PET With 11C-AC-5216. J Nucl Med (2009) 50(7):1095. doi: 10.2967/jnumed.109.062554

64. Zhou X, Ji B, Seki C, Nagai Y, Minamimoto T, Fujinaga M, et al. PET Imaging of Colony-Stimulating Factor 1 Receptor: A Head-to-Head Comparison of a Novel Radioligand, (11)C-GW2580, and (11)C-CPPC, in Mouse Models of Acute and Chronic Neuroinflammation and a Rhesus Monkey. J Cereb Blood Flow Metab (2021) 41(9):2410-22. doi: 10.1177/ $0271678 \times 211004146$

65. Takuwa H, Orihara A, Takado Y, Urushihata T, Shimojo M, Ishikawa A, et al. Tracking Tau Fibrillogenesis and Consequent Primary Phagocytosis of 
Neurons Mediated by Microglia in a Living Tauopathy Model. bioRxiv (2020) 2020.11.04.368977. doi: 10.1101/2020.11.04.368977

66. Suridjan I, Pollock BG, Verhoeff NP, Voineskos AN, Chow T, Rusjan PM, et al. In-Vivo Imaging of Grey and White Matter Neuroinflammation in Alzheimer's Disease: A Positron Emission Tomography Study With a Novel Radioligand, [18F]-FEPPA. Mol Psychiatry (2015) 20(12):1579-87. doi: $10.1038 / \mathrm{mp} .2015 .1$

67. Knezevic D, Verhoeff NPL, Hafizi S, Strafella AP, Graff-Guerrero A, Rajji T, et al. Imaging Microglial Activation and Amyloid Burden in Amnestic Mild Cognitive Impairment. J Cereb Blood Flow Metab (2018) 38(11):1885-95. doi: $10.1177 / 0271678 \times 17741395$

68. Al-Khishman NU, Qi Q, Roseborough AD, Levit A, Allman BL, Anazodo UC, et al. TSPO PET Detects Acute Neuroinflammation But Not Diffuse Chronically Activated MHCII Microglia in the Rat. EJNMMI Res (2020) 10 (1):113. doi: 10.1186/s13550-020-00699-x

69. Dani M, Wood M, Mizoguchi R, Fan Z, Walker Z, Morgan R, et al. Microglial Activation Correlates In Vivo With Both Tau and Amyloid in Alzheimer's Disease. Brain (2018) 141(9):2740-54. doi: 10.1093/brain/ awy 188

70. Giridharan VV, Collodel A, Generoso JS, Scaini G, Wassather R, Selvaraj S, et al. Neuroinflammation Trajectories Precede Cognitive Impairment After Experimental Meningitis-Evidence From an In Vivo PET Study. J Neuroinflamm (2020) 17(1):5. doi: 10.1186/s12974-019-1692-0

71. Toppala S, Ekblad LL, Tuisku J, Helin S, Johansson JJ, Laine H, et al. Association of Early $\beta$-Amyloid Accumulation and Neuroinflammation Measured With [(11)C]PBR28 in Elderly Individuals Without Dementia. Neurology (2021) 96(12):e1608-19. doi: 10.1212/wnl.0000000000011612

72. James ML, Belichenko NP, Nguyen TV, Andrews LE, Ding Z, Liu H, et al. PET Imaging of Translocator Protein $(18 \mathrm{kDa})$ in a Mouse Model of Alzheimer's Disease Using N-(2,5-Dimethoxybenzyl)-2-18F-Fluoro-N-(2Phenoxyphenyl)Acetamide. J Nucl Med (2015) 56(2):311-6. doi: 10.2967/ jnumed.114.141648

73. Mirzaei N, Tang SP, Ashworth S, Coello C, Plisson C, Passchier J, et al. In Vivo Imaging of Microglial Activation by Positron Emission Tomography With [(11)C]PBR28 in the 5XFAD Model of Alzheimer's Disease. Glia (2016) 64(6):993-1006. doi: 10.1002/glia.22978

74. Zou J, Tao S, Johnson A, Tomljanovic Z, Polly K, Klein J, et al. Microglial Activation, But Not Tau Pathology, is Independently Associated With Amyloid Positivity and Memory Impairment. Neurobiol Aging (2020) 85:11-21. doi: 10.1016/j.neurobiolaging.2019.09.019

75. Zanotti-Fregonara P, Pascual B, Veronese M, Yu M, Beers D, Appel SH, et al. Head-To-Head Comparison of (11)C-PBR28 and (11)C-ER176 for Quantification of the Translocator Protein in the Human Brain. Eur $J$ Nucl Med Mol Imaging (2019) 46(9):1822-9. doi: 10.1007/s00259-01904349-w

76. Zanotti-Fregonara P, Pascual B, Rizzo G, Yu M, Pal N, Beers D, et al. HeadTo-Head Comparison of (11)C-PBR28 and (18)F-GE180 for Quantification of the Translocator Protein in the Human Brain. J Nucl Med (2018) 59 (8):1260-6. doi: 10.2967/jnumed.117.203109

77. Pascual B, Funk Q, Zanotti-Fregonara P, Cykowski MD, Veronese M, Rockers E, et al. Neuroinflammation is Highest in Areas of Disease Progression in Semantic Dementia. Brain (2021) 44(5):1565-75. doi: 10.1093/brain/awab057

78. Walker MD, Dinelle K, Kornelsen R, Lee NV, Miao Q, Adam M, et al. [11c] PBR28 PET Imaging is Sensitive to Neuroinflammation in the Aged Rat. J Cereb Blood Flow Metab (2015) 35(8):1331-8. doi: 10.1038/jcbfm.2015.54

79. Schain M, Zanderigo F, Ogden RT, Kreisl WC. Non-Invasive Estimation of [(11)C]PBR28 Binding Potential. Neuroimage (2018) 169:278-85. doi: 10.1016/j.neuroimage.2017.12.002

80. Donat CK, Mirzaei N, Tang SP, Edison P, Sastre M. Imaging of Microglial Activation in Alzheimer's Disease by [(11)C]PBR28 PET. Methods Mol Biol (2018) 1750:323-39. doi: 10.1007/978-1-4939-7704-8_22

81. Xu J, Sun J, Perrin RJ, Mach RH, Bales KR, Morris JC, et al. Translocator Protein in Late Stage Alzheimer's Disease and Dementia With Lewy Bodies Brains. Ann Clin Transl Neurol (2019) 6(8):1423-34. doi: 10.1002/ acn 3.50837

82. Kim MJ, McGwier M, Jenko KJ, Snow J, Morse C, Zoghbi SS, et al. Neuroinflammation in Frontotemporal Lobar Degeneration Revealed by
(11) C-PBR28 PET. Ann Clin Transl Neurol (2019) 6(7):1327-31. doi: $10.1002 /$ acn 3.50802

83. Eberl S, Katsifis A, Peyronneau MA, Wen L, Henderson D, Loc'h C, et al. Preclinical In Vivo and In Vitro Comparison of the Translocator Protein PET Ligands [(18)F]PBR102 and [(18)F]PBR111. Eur J Nucl Med Mol Imaging (2017) 44(2):296-307. doi: 10.1007/s00259-016-3517-z

84. Deleye S, Waldron AM, Verhaeghe J, Bottelbergs A, Wyffels L, Van Broeck B, et al. Evaluation of Small-Animal PET Outcome Measures to Detect Disease Modification Induced by BACE Inhibition in a Transgenic Mouse Model of Alzheimer Disease. J Nucl Med (2017) 58(12):1977-83. doi: 10.2967/jnumed.116.187625

85. Tournier BB, Tsartsalis S, Ceyzériat K, Fraser BH, Grégoire MC, Kövari E, et al. Astrocytic TSPO Upregulation Appears Before Microglial TSPO in Alzheimer's Disease. J Alzheimers Dis (2020) 77(3):1043-56. doi: 10.3233/ jad-200136

86. Tournier BB, Tsartsalis S, Rigaud D, Fossey C, Cailly T, Fabis F, et al. TSPO and Amyloid Deposits in Sub-Regions of the Hippocampus in the 3xtgad Mouse Model of Alzheimer's Disease. Neurobiol Dis (2019) 121:95-105. doi: 10.1016/j.nbd.2018.09.022

87. Szöllősi D, Hegedűs N, Veres DS, Futó I, Horváth I, Kovács N, et al. Evaluation of Brain Nuclear Medicine Imaging Tracers in a Murine Model of Sepsis-Associated Encephalopathy. Mol Imaging Biol (2018) 20(6):952-62. doi: 10.1007/s11307-018-1201-3

88. Vettermann F, Harris S, Schmitt J, Unterrainer M, Lindner S, Rauchmann B-S, et al. Impact of TSPO Receptor Polymorphism on [18F]GE-180 Binding in Healthy Brain and Pseudo-Reference Regions of Neurooncological and Neurodegenerative Disorders. Life (2021) 11:484. doi: 10.3390/life11060484

89. Palleis C, Sauerbeck J, Beyer L, Harris S, Schmitt J, Morenas-Rodriguez E, et al. In Vivo Assessment of Neuroinflammation in 4-Repeat Tauopathies. Mov Disord (2021) 36(4):883-94. doi: 10.1002/mds.28395

90. López-Picón FR, Snellman A, Eskola O, Helin S, Solin O, Haaparanta-Solin $M$, et al. Neuroinflammation Appears Early on PET Imaging and Then Plateaus in a Mouse Model of Alzheimer Disease. J Nucl Med (2018) 59 (3):509. doi: 10.2967/jnumed.117.197608

91. Kaiser L, Albert N, Lindner S, Unterrainer M, Mahler C, Brendel M, et al. TSPO Imaging Using the Novel PET Ligand [18F]GE-180: Quantification Approaches in Patients With Multiple Sclerosis. EJNMMI Res 7(2017) 45 (8):1423-31. doi: 10.1186/s13550-017-0340-x

92. Liu B, Le KX, Park MA, Wang S, Belanger AP, Dubey S, et al. In Vivo Detection of Age- and Disease-Related Increases in Neuroinflammation by 18F-GE180 TSPO MicroPET Imaging in Wild-Type and Alzheimer's Transgenic Mice. J Neurosci (2015) 35(47):15716-30. doi: 10.1523/jneurosci.0996-15.2015

93. Blume T, Focke C, Peters F, Deussing M, Albert NL, Lindner S, et al. Microglial Response to Increasing Amyloid Load Saturates With Aging: A Longitudinal Dual Tracer In Vivo upet-Study. J Neuroinflamm (2018) 15 (1):307. doi: 10.1186/s12974-018-1347-6

94. James ML, Belichenko NP, Shuhendler AJ, Hoehne A, Andrews LE, Condon C, et al. [(18)F]GE-180 PET Detects Reduced Microglia Activation After LM11A-31 Therapy in a Mouse Model of Alzheimer's Disease. Theranostics (2017) 7(6):1422-36. doi: 10.7150/thno.17666

95. Biechele G, Wind K, Blume T, Sacher C, Beyer L, Eckenweber F, et al. Microglial Activation in the Right Amygdala-Entorhinal-Hippocampal Complex Is Associated With Preserved Spatial Learning in App(NL-G-F) Mice. Neuroimage (2021) 230:117707. doi: 10.1016/j.neuroimage.2020.117707

96. Sacher C, Blume T, Beyer L, Biechele G, Sauerbeck J, Eckenweber F, et al. Asymmetry of Fibrillar Plaque Burden in Amyloid Mouse Models. J Nucl Med (2020) 61(12):1825-31. doi: 10.2967/jnumed.120.242750

97. Kleinberger G, Brendel M, Mracsko E, Wefers B, Groeneweg L, Xiang X, et al. The FTD-Like Syndrome Causing TREM2 T66M Mutation Impairs Microglia Function, Brain Perfusion, and Glucose Metabolism. EMBO J (2017) 36(13):1837-53. doi: 10.15252/embj.201796516

98. Eckenweber F, Medina-Luque J, Blume T, Sacher C, Biechele G, Wind K, et al. Longitudinal TSPO Expression in Tau Transgenic P301S Mice Predicts Increased Tau Accumulation and Deteriorated Spatial Learning. J Neuroinflamm (2020) 17(1):208. doi: 10.1186/s12974-020-01883-5

99. Biechele G, Blume T, Deussing M, Zott B, Shi Y, Xiang X, et al. PreTherapeutic Microglia Activation and Sex Determine Therapy Effects of Chronic Immunomodulation. bioRxiv (2021). doi: 10.1101/2021.05.30.445761 
100. Liu B, Hinshaw RG, Le KX, Park M-A, Wang S, Belanger AP, et al. SpaceLike 56Fe Irradiation Manifests Mild, Early Sex-Specific Behavioral and Neuropathological Changes in Wildtype and Alzheimer's-Like Transgenic Mice. Sci Rep (2019) 9(1):12118. doi: 10.1038/s41598-019-48615-1

101. Ewers M, Biechele G, Suárez-Calvet M, Sacher C, Blume T, MorenasRodriguez E, et al. Higher CSF Strem2 and Microglia Activation are Associated With Slower Rates of Beta-Amyloid Accumulation. EMBO Mol Med (2020) 12(9):e12308. doi: 10.15252/emmm.202012308

102. Boutin H, Murray K, Pradillo J, Maroy R, Smigova A, Gerhard A, et al. 18fGE-180: A Novel TSPO Radiotracer Compared to 11C-R-PK11195 in a Preclinical Model of Stroke. Eur J Nucl Med Mol Imaging (2015) 42(3):50311. doi: 10.1007/s00259-014-2939-8

103. Ramakrishnan NK, Hird M, Thompson S, Williamson DJ, Qiao L, Owen DR, et al. Preclinical Evaluation of (S)-[18f]GE387, a Novel 18-kDa Translocator Protein (TSPO) PET Radioligand With Low Binding Sensitivity to Human Polymorphism Rs6971. Eur J Nucl Med Mol Imaging (2021). doi: 10.1007/ s00259-021-05495-w

104. Qiao L, Fisher E, McMurray L, Milicevic Sephton S, Hird M, KuzhuppillyRamakrishnan N, et al. Radiosynthesis of (R,S)-[(18) F]GE387: A Potential PET Radiotracer for Imaging Translocator Protein $18 \mathrm{kDa}$ (TSPO) With Low Binding Sensitivity to the Human Gene Polymorphism Rs6971. ChemMedChem (2019) 14(9):982-93. doi: 10.1002/cmdc.201900023

105. Ikawa M, Lohith TG, Shrestha S, Telu S, Zoghbi SS, Castellano S, et al. 11cER176, a Radioligand for $18-\mathrm{kDa}$ Translocator Protein, Has Adequate Sensitivity to Robustly Image All Three Affinity Genotypes in Human Brain. J Nucl Med Off Publ Soc Nucl Med (2017) 58(2):320-5. doi: 10.2967/ jnumed.116.178996

106. Fujita M, Kobayashi M, Ikawa M, Gunn RN, Rabiner EA, Owen DR, et al. Comparison of Four 11C-Labeled PET Ligands to Quantify Translocator Protein $18 \mathrm{kDa}$ (TSPO) in Human Brain: (R)-PK11195, PBR28, DPA-713, and ER176-based on Recent Publications That Measured Specific-to-nonDisplaceable Ratios. EJNMMI Res (2017) 7(1):84. doi: 10.1186/s13550-0170334-8

107. Hatano K, Sekimata K, Yamada T, Abe J, Ito K, Ogawa M, et al. Radiosynthesis and In Vivo Evaluation of Two Imidazopyridineacetamides, [11C]CB184 and [11C]CB190, as a PET Tracer for $18 \mathrm{kDa}$ Translocator Protein: Direct Comparison With [11C](R)-Pk11195. Ann Nucl Med (2015) 29(4):325-35. doi: 10.1007/s12149-015-0948-8

108. Tiwari AK, Zhang Y, Yamasaki T, Kumari N, Fujinaga M, Mori W, et al. Radiosynthesis and Evaluation of Acetamidobenzoxazolone Based Radioligand [11C] $\mathrm{N}^{\prime}$-MPB for Visualization of $18 \mathrm{kDa}$ TSPO in Brain. New J Chem (2020) 44(19):7912-22. doi: 10.1039/D0NJ00509F

109. MacAskill MG, Stadulyte A, Williams L, Morgan TEF, Sloan NL, AlcaideCorral CJ, et al. Quantification of Macrophage-Driven Inflammation During Myocardial Infarction With 18F-LW223, a Novel TSPO Radiotracer With Binding Independent of the Rs6971 Human Polymorphism. J Nucl Med (2021) 62(4):536. doi: 10.2967/jnumed.120.243600

110. Han J, Liu H, Liu C, Jin H, Perlmutter JS, Egan TM, et al. Pharmacologic Characterizations of a P2X7 Receptor-Specific Radioligand, [11C] GSK1482160 for Neuroinflammatory Response. Nucl Med Commun (2017) 38(5):372-82. doi: 10.1097/mnm.0000000000000660

111. Territo PR, Meyer JA, Peters JS, Riley AA, McCarthy BP, Gao M, et al. Characterization of (11)C-GSK1482160 for Targeting the P2X7 Receptor as a Biomarker for Neuroinflammation. J Nucl Med (2017) 58(3):458-65. doi: $10.2967 /$ jnumed.116.181354

112. Koole M, Schmidt ME, Hijzen A, Ravenstijn P, Vandermeulen C, Van Weehaeghe D, et al. (18)F-JNJ-64413739, a Novel PET Ligand for the P2X7 Ion Channel: Radiation Dosimetry, Kinetic Modeling, Test-Retest Variability, and Occupancy of the P2X7 Antagonist JNJ-54175446. J Nucl Med (2019) 60(5):683-90. doi: 10.2967/jnumed.118.216747

113. Van Weehaeghe D, Van Schoor E, De Vocht J, Koole M, Attili B, Celen S, et al. TSPO Versus P2X7 as a Target for Neuroinflammation: An In Vitro and In Vivo Study. J Nucl Med (2020) 61(4):604-7. doi: 10.2967/ jnumed.119.231985

114. Berdyyeva T, Xia C, Taylor N, He Y, Chen G, Huang C, et al. PET Imaging of the P2X7 Ion Channel With a Novel Tracer [(18)F]JNJ-64413739 in a Rat Model of Neuroinflammation. Mol Imaging Biol (2019) 21(5):871-8. doi: 10.1007/s11307-018-01313-2
115. Ory D, Celen S, Gijsbers R, Van Den Haute C, Postnov A, Koole M, et al. Preclinical Evaluation of a P2X7 Receptor-Selective Radiotracer: PET Studies in a Rat Model With Local Overexpression of the Human P2X7 Receptor and in Nonhuman Primates. J Nucl Med (2016) 57(9):1436-41. doi: 10.2967/ jnumed.115.169995

116. Crabbé M, van der Perren A, Bollaerts I, Kounelis S, Baekelandt V, Bormans G, et al. Increased P2X7 Receptor Binding Is Associated With Neuroinflammation in Acute But Not Chronic Rodent Models for Parkinson's Disease. Front Neurosci (2019) 13:799. doi: 10.3389/fnins.2019.00799

117. Hagens MHJ, Golla SSV, Janssen B, Vugts DJ, Beaino W, Windhorst AD, et al. The P2X7 Receptor Tracer [11C]SMW139 as an In Vivo Marker of Neuroinflammation in Multiple Sclerosis: A First-in Man Study. Eur J Nucl Med Mol Imaging (2020) 47(2):379-89. doi: 10.1007/s00259-019-04550-x

118. Beaino W, Janssen B, Kooijman E, Vos R, Schuit RC, O’Brien-Brown J, et al. PET Imaging of P2X7R in the Experimental Autoimmune Encephalomyelitis Model of Multiple Sclerosis Using [11C]SMW139. J Neuroinflamm (2020) 17 (1):300. doi: 10.1186/s12974-020-01962-7

119. Janssen B, Vugts DJ, Wilkinson SM, Ory D, Chalon S, Hoozemans JJM, et al. Identification of the Allosteric P2X7 Receptor Antagonist [11C]SMW139 as a PET Tracer of Microglial Activation. Sci Rep (2018) 8(1):6580. doi: 10.1038/ s41598-018-24814-0

120. Beaino W, Janssen B, Kooij G, van der Pol SMA, van Het Hof B, van Horssen J, et al. Purinergic Receptors P2Y12R and P2X7R: Potential Targets for PET Imaging of Microglia Phenotypes in Multiple Sclerosis. J Neuroinflamm (2017) 14(1):259. doi: 10.1186/s12974-017-1034-z

121. Janssen B, Vugts DJ, Funke U, Spaans A, Schuit RC, Kooijman E, et al. Synthesis and Initial Preclinical Evaluation of the P2X7 Receptor Antagonist $\left[{ }^{11} \mathrm{C}\right] \mathrm{A}-740003$ as a Novel Tracer of Neuroinflammation. J Labelled Comp Radiopharm (2014) 57(8):509-16. doi: 10.1002/jlcr.3206

122. Villa A, Klein B, Janssen B, Pedragosa J, Pepe G, Zinnhardt B, et al. Identification of New Molecular Targets for PET Imaging of the Microglial Anti-Inflammatory Activation State. Theranostics (2018) 8(19):5400-18. doi: 10.7150/thno. 25572

123. Maeda J, Minamihisamatsu T, Shimojo M, Zhou X, Ono M, Matsuba Y, et al. Distinct Microglial Response Against Alzheimer's Amyloid and Tau Pathologies Characterized by P2Y12 Receptor. Brain Commun (2021) 3(1): fcab011. doi: 10.1093/braincomms/fcab011

124. Horti AG, Naik R, Foss CA, Minn I, Misheneva V, Du Y, et al. PET Imaging of Microglia by Targeting Macrophage Colony-Stimulating Factor 1 Receptor (CSF1R). Proc Natl Acad Sci USA (2019) 116(5):1686-91. doi: $10.1073 /$ pnas. 1812155116

125. Ohnishi A, Senda M, Yamane T, Sasaki M, Mikami T, Nishio T, et al. Human Whole-Body Biodistribution and Dosimetry of a New PET Tracer, $[(11) \mathrm{C}]$ ketoprofen Methyl Ester, for Imagings of Neuroinflammation. Nucl Med Biol (2014) 41(7):594-9. doi: 10.1016/j.nucmedbio.2014.04.008

126. Ohnishi A, Senda M, Yamane T, Mikami T, Nishida H, Nishio T, et al. Exploratory Human PET Study of the Effectiveness of (11)C-Ketoprofen Methyl Ester, a Potential Biomarker of Neuroinflammatory Processes in Alzheimer's Disease. Nucl Med Biol (2016) 43(7):438-44. doi: 10.1016/ j.nucmedbio.2016.04.005

127. Shukuri M, Mawatari A, Ohno M, Suzuki M, Doi H, Watanabe Y, et al. Detection of Cyclooxygenase-1 in Activated Microglia During Amyloid Plaque Progression: PET Studies in Alzheimer's Disease Model Mice. J Nucl Med (2016) 57(2):291-6. doi: 10.2967/jnumed.115.166116

128. Shrestha S, Singh P, Cortes-Salva MY, Jenko KJ, Ikawa M, Kim M-J, et al. 3Substituted 1,5-Diaryl-1 H-1,2,4-Triazoles as Prospective PET Radioligands for Imaging Brain COX-1 in Monkey. Part 2: Selection and Evaluation of [(11)C]PS13 for Quantitative Imaging. ACS Chem Neurosci (2018) 9 (11):2620-7. doi: 10.1021/acschemneuro.8b00103

129. Shrestha S, Kim MJ, Eldridge M, Lehmann ML, Frankland M, Liow JS, et al. PET Measurement of Cyclooxygenase-2 Using a Novel Radioligand: Upregulation in Primate Neuroinflammation and First-in-Human Study. J Neuroinflamm (2020) 17(1):140. doi: 10.1186/s12974-020-01804-6

130. Kumar JSD, Prabhakaran J, Molotkov A, Sattiraju A, Kim J, Doubrovin M, et al. Radiosynthesis and Evaluation of [(18)F]FMTP, a COX-2 PET Ligand. Pharmacol Rep (2020) 72(5):1433-40. doi: 10.1007/s43440-020-00124-Z

131. Kumar JSD, Zanderigo F, Prabhakaran J, Rubin-Falcone H, Parsey RV, Mann JJ. In Vivo Evaluation of [11C]TMI, a COX-2 Selective PET Tracer, in 
Baboons. Bioorg Med Chem Lett (2018) 28(23):3592-5. doi: 10.1016/ j.bmcl.2018.10.049

132. Yeh SH, Huang WS, Chiu CH, Chen CL, Chen HT, Chi DY, et al. Automated Synthesis and Initial Evaluation of (4'-Amino-5',8'-Difluoro-1'H-Spiro [Piperidine-4,2'-Quinazolin]-1-Yl)(4-[(18)F]fluorophenyl)methanone for PET/MR Imaging of Inducible Nitric Oxide Synthase. Mol Imaging (2021) 2021:9996125. doi: 10.1155/2021/9996125

133. Hou C, Hsieh C-J, Li S, Lee H, Graham TJ, Xu K, et al. Development of a Positron Emission Tomography Radiotracer for Imaging Elevated Levels of Superoxide in Neuroinflammation. ACS Chem Neurosci (2018) 9(3):578-86. doi: 10.1021/acschemneuro.7b00385

134. Egami H, Nakagawa S, Katsura Y, Kanazawa M, Nishiyama S, Sakai T, et al. (18)F-Labeled Dihydromethidine: Positron Emission Tomography Radiotracer for Imaging of Reactive Oxygen Species in Intact Brain. Org Biomol Chem (2020) 18(13):2387-91. doi: 10.1039/d0ob00126k

135. Carroll VN, Truillet C, Shen B, Flavell RR, Shao X, Evans MJ, et al. [11c] Ascorbic and [11C]Dehydroascorbic Acid, an Endogenous Redox Pair for Sensing Reactive Oxygen Species Using Positron Emission Tomography. Chem Commun (2016) 52(27):4888-90. doi: 10.1039/C6CC00895J

136. Ikawa M, Okazawa H, Tsujikawa T, Matsunaga A, Yamamura O, Mori T, et al. Increased Oxidative Stress is Related to Disease Severity in the ALS Motor Cortex: A PET Study. Neurology (2015) 84(20):2033-9. doi: 10.1212/ wnl.0000000000001588

137. Ikawa M, Okazawa H, Kudo T, Kuriyama M, Fujibayashi Y, Yoneda M. Evaluation of Striatal Oxidative Stress in Patients With Parkinson's Disease Using [62Cu]ATSM PET. Nucl Med Biol (2011) 38(7):945-51. doi: 10.1016/ j.nucmedbio.2011.02.016

138. Fujibayashi Y, Taniuchi H, Yonekura Y, Ohtani H, Konishi J, Yokoyama A. Copper-62-ATSM: A New Hypoxia Imaging Agent With High Membrane Permeability and Low Redox Potential. J Nucl Med (1997) 38(7):1155-60.

139. Tsujikawa T, Asahi S, Oh M, Sato Y, Narita N, Makino A, et al. Assessment of the Tumor Redox Status in Head and Neck Cancer by 62Cu-ATSM PET. PloS One (2016) 11(5):e0155635. doi: 10.1371/journal.pone.0155635

140. Meier SR, Sehlin D, Hultqvist G, Syvänen S. Pinpointing Brain TREM2 Levels in Two Mouse Models of Alzheimer's Disease. Mol Imaging Biol (2021) 23:s665-75. doi: 10.1007/s11307-021-01591-3

141. Chaney A, Wilson E, Jain P, Cropper H, Swarovski M, Lucot K, et al. TREM1-PET Imaging of Pro-Inflammatory Myeloid Cells Distinguishes Active Disease From Remission in Multiple Sclerosis. J Nucl Med (2020) 61(supplement 1):199.

142. Johnson E, Murty S, Mayer A, Tsai C, Mehta S, Ilovich O, et al. TMIC-30. TREM1-TARGETED PET IMAGING OF TUMOR-ASSOCIATED MACROPHAGES IN AN ORTHOTOPIC GLIOBLASTOMA MOUSE MODEL. Neuro-Oncology (2017) 19(suppl_6):vi249-9. doi: 10.1093/ neuonc/nox168.1019

143. Liu Q, Johnson EM, Lam RK, Wang Q, Bo Ye H, Wilson EN, et al. Peripheral TREM1 Responses to Brain and Intestinal Immunogens Amplify Stroke Severity. Nat Immunol (2019) 20(8):1023-34. doi: 10.1038/s41590-019-0421-2

144. Zheng Q-H, Fei X, DeGrado TR, Wang J-Q, Lee Stone K, Martinez TD, et al. Synthesis, Biodistribution and Micro-PET Imaging of a Potential Cancer Biomarker Carbon-11 Labeled MMP Inhibitor (2R)-2-[[4-(6-Fluorohex-1Ynyl)Phenyl]Sulfonylamino]-3-Methylbutyric Acid [11C]Methyl Ester. Nucl Med Biol (2003) 30(7):753-60. doi: 10.1016/S0969-8051(03)00086-6

145. Kasten BB, Jiang K, Cole D, Jani A, Udayakumar N, Gillespie GY, et al. Targeting MMP-14 for Dual PET and Fluorescence Imaging of Glioma in Preclinical Models. Eur J Nucl Med Mol Imaging (2020) 47(6):1412-26. doi: 10.1007/s00259-019-04607-x

146. Butsch V, Börgel F, Galla F, Schwegmann K, Hermann S, Schäfers M, et al. Design, (Radio)Synthesis, and in Vitro and In Vivo Evaluation of Highly Selective and Potent Matrix Metalloproteinase 12 (MMP-12) Inhibitors as Radiotracers for Positron Emission Tomography. J Med Chem (2018) 61 (9):4115-34. doi: 10.1021/acs.jmedchem.8b00200

147. Barca C, Foray C, Hermann S, Döring C, Schäfers M, Jacobs AH, et al. Characterization of the Inflammatory Post-Ischemic Tissue by Full Volumetric Analysis of a Multimodal Imaging Dataset. NeuroImage (2020) 222:117217. doi: 10.1016/j.neuroimage.2020.117217

148. Zinnhardt B, Viel T, Wachsmuth L, Vrachimis A, Wagner S, Breyholz H-J, et al. Multimodal Imaging Reveals Temporal and Spatial Microglia and
Matrix Metalloproteinase Activity After Experimental Stroke. J Cereb Blood Flow Metab (2015) 35(11):1711-21. doi: 10.1038/jcbfm.2015.149

149. Caillé F, Cacheux F, Peyronneau MA, Jego B, Jaumain E, Pottier G, et al. From Structure-Activity Relationships on Thiazole Derivatives to the In Vivo Evaluation of a New Radiotracer for Cannabinoid Subtype 2 PET Imaging. Mol Pharm (2017) 14(11):4064-78. doi: 10.1021/acs.molpharmaceut. $7 \mathrm{~b} 00746$

150. Savonenko AV, Melnikova T, Wang Y, Ravert H, Gao Y, Koppel J, et al. Cannabinoid CB2 Receptors in a Mouse Model of A $\beta$ Amyloidosis: Immunohistochemical Analysis and Suitability as a PET Biomarker of Neuroinflammation. PloS One (2015) 10(6):e0129618. doi: 10.1371/ journal.pone.0129618

151. Ni R, Müller Herde A, Haider A, Keller C, Louloudis G, Vaas M, et al. In Vivo Imaging of Cannabinoid Type 2 Receptors, Functional and Structural Alterations in Mouse Model of Cerebral Ischemia by PET and MRI. bioRxiv (2021) 2021:5.08.441033. doi: 10.1101/2021.05.08.441033

152. Ni R, Mu L, Ametamey S. Positron Emission Tomography of Type 2 Cannabinoid Receptors for Detecting Inflammation in the Central Nervous System. Acta Pharmacol Sin (2019) 40(3):351-7. doi: 10.1038/ s41401-018-0035-5

153. Moldovan R-P, Teodoro R, Gao Y, Deuther-Conrad W, Kranz M, Wang Y, et al. Development of a High-Affinity PET Radioligand for Imaging Cannabinoid Subtype 2 Receptor. J Med Chem (2016) 59(17):7840-55. doi: 10.1021/acs.jmedchem.6b00554

154. Ahmad R, Postnov A, Bormans G, Versijpt J, Vandenbulcke M, Van Laere K. Decreased In Vivo Availability of the Cannabinoid Type 2 Receptor in Alzheimer's Disease. Eur J Nucl Med Mol Imaging (2016) 43(12):2219-27. doi: 10.1007/s00259-016-3457-7

155. Yamagishi S, Iga Y, Nakamura M, Takizawa C, Fukumoto D, Kakiuchi T, et al. Upregulation of Cannabinoid Receptor Type 2, But Not TSPO, in Senescence-Accelerated Neuroinflammation in Mice: A Positron Emission Tomography Study. J Neuroinflamm (2019) 16(1):208. doi: 10.1186/s12974019-1604-3

156. Vilaplana E, Rodriguez-Vieitez E, Ferreira D, Montal V, Almkvist O, Wall A, et al. Cortical Microstructural Correlates of Astrocytosis in AutosomalDominant Alzheimer Disease. Neurology (2020) 94(19):e2026-36. doi: 10.1212/wnl.0000000000009405

157. Lemoine L, Gillberg PG, Bogdanovic N, Nennesmo I, Saint-Aubert L, Viitanen M, et al. Amyloid, Tau, and Astrocyte Pathology in AutosomalDominant Alzheimer's Disease Variants: Aßpparc and PSEN1DE9. Mol Psychiatry (2020). doi: 10.1038/s41380-020-0817-2

158. Marutle A, Gillberg PG, Bergfors A, Yu WF, Ni RQ, Nennesmo I, et al. H-3Deprenyl and H-3-PIB Autoradiography Show Different Laminar Distributions of Astroglia and Fibrillar Beta-Amyloid in Alzheimer Brain. J Neuroinflamm (2013) 10:861. doi: 10.1186/1742-2094-10-90

159. Carter SF, Chiotis K, Nordberg A, Rodriguez-Vieitez E. Longitudinal Association Between Astrocyte Function and Glucose Metabolism in Autosomal Dominant Alzheimer's Disease. Eur J Nucl Med Mol Imaging (2019) 46(2):348-56. doi: 10.1007/s00259-018-4217-7

160. Rodriguez-Vieitez E, Carter SF, Chiotis K, Saint-Aubert L, Leuzy A, Schöll $\mathrm{M}$, et al. Comparison of Early-Phase 11c-Deuterium-L-Deprenyl and 11CPittsburgh Compound B PET for Assessing Brain Perfusion in Alzheimer Disease. J Nucl Med (2016) 57(7):1071-7. doi: 10.2967/jnumed.115.168732

161. Schöll M, Carter SF, Westman E, Rodriguez-Vieitez E, Almkvist O, Thordardottir S, et al. Early Astrocytosis in Autosomal Dominant Alzheimer's Disease Measured In Vivo by Multi-Tracer Positron Emission Tomography. Sci Rep (2015) 5:16404. doi: 10.1038/srep16404

162. Rodriguez-Vieitez E, Saint-Aubert L, Carter SF, Almkvist O, Farid K, Schöll $\mathrm{M}$, et al. Diverging Longitudinal Changes in Astrocytosis and Amyloid PET in Autosomal Dominant Alzheimer's Disease. Brain (2016) 139(Pt 3):92236. doi: 10.1093/brain/awv404

163. Rodriguez-Vieitez E, Ni RQ, Gulyas B, Toth M, Haggkvist J, Halldin C, et al. Astrocytosis Precedes Amyloid Plaque Deposition in Alzheimer APPswe Transgenic Mouse Brain: A Correlative Positron Emission Tomography and In Vitro Imaging Study. Eur J Nucl Med Mol Imaging (2015) 42(7):1119-32. doi: $10.1007 / \mathrm{s} 00259-015-3047-0$

164. Olsen M, Aguilar X, Sehlin D, Fang XT, Antoni G, Erlandsson A, et al. Astroglial Responses to Amyloid-Beta Progression in a Mouse Model of 
Alzheimer's Disease. Mol Imaging Biol (2018) 20(4):605-14. doi: 10.1007/ s11307-017-1153-z

165. Nag S, Fazio P, Lehmann L, Kettschau G, Heinrich T, Thiele A, et al. In Vivo and In Vitro Characterization of a Novel MAO-B Inhibitor Radioligand, 18fLabeled Deuterated Fluorodeprenyl. J Nucl Med (2016) 57(2):315-20. doi: 10.2967/jnumed.115.161083

166. Harada R, Hayakawa Y, Ezura M, Lerdsirisuk P, Du Y, Ishikawa Y, et al. (18) F-SMBT-1: A Selective and Reversible PET Tracer for Monoamine OxidaseB Imaging. J Nucl Med (2021) 62(2):253-8. doi: 10.2967/jnumed.120.244400

167. Villemagne VLL, Harada R, Dore V, Furumoto S, Mulligan RS, Kudo Y, et al. Evaluation of the Novel 18F-Labeled PET Tracer SMBT-1 for Imaging Astrogliosis in Healthy Elderly Controls and $\mathrm{A}+/ \mathrm{T}+/(\mathrm{N}+)$ Alzheimer's Disease Patients. Alzheimer's Dementia (2020) 16(S4):e039858. doi: 10.1002/alz.039858

168. Moriguchi S, Wilson AA, Miler L, Rusjan PM, Vasdev N, Kish SJ, et al. Monoamine Oxidase B Total Distribution Volume in the Prefrontal Cortex of Major Depressive Disorder: An [11c]SL25.1188 Positron Emission Tomography Study. JAMA Psychiatry (2019) 76(6):634-41. doi: 10.1001/ jamapsychiatry.2019.0044

169. Rusjan PM, Wilson AA, Miler L, Fan I, Mizrahi R, Houle S, et al. Kinetic Modeling of the Monoamine Oxidase B Radioligand $\left[{ }^{11} \mathrm{C}\right]$ SL25.1188 in Human Brain With High-Resolution Positron Emission Tomography. J Cereb Blood Flow Metab (2014) 34(5):883-9. doi: 10.1038/jcbfm.2014.34

170. Narayanaswami V, Drake LR, Brooks AF, Meyer JH, Houle S, Kilbourn MR, et al. Classics in Neuroimaging: Development of PET Tracers for Imaging Monoamine Oxidases. ACS Chem Neurosci (2019) 10(4):1867-71. doi: 10.1021/acschemneuro.9b00081

171. Takata K, Kato H, Shimosegawa E, Okuno T, Koda T, Sugimoto T, et al. 11cAcetate PET Imaging in Patients With Multiple Sclerosis. PloS One (2014) 9 (11):e111598. doi: 10.1371/journal.pone.0111598

172. Duong MT, Chen YJ, Doot RK, Young AJ, Lee H, Cai J, et al. Astrocyte Activation Imaging With 11C-Acetate and Amyloid PET in Mild Cognitive Impairment Due to Alzheimer Pathology. Nucl Med Commun (2021). doi: $10.1097 / \mathrm{mnm} .0000000000001460$

173. Kumar A, Koistinen NA, Malarte ML, Nennesmo I, Ingelsson M, Ghetti B, et al. Astroglial Tracer BU99008 Detects Multiple Binding Sites in Alzheimer's Disease Brain. Mol Psychiatry (2021). doi: 10.1038/s41380021-01101-5

174. Wilson H, Dervenoulas G, Pagano G, Tyacke RJ, Polychronis S, Myers J, et al. Imidazoline 2 Binding Sites Reflecting Astroglia Pathology in Parkinson's Disease: An In Vivo 11c-BU99008 PET Study. Brain (2019) 142(10):311628. doi: 10.1093/brain/awz260

175. Tyacke RJ, Myers JFM, Venkataraman A, Mick I, Turton S, Passchier J, et al. Evaluation of (11)C-BU99008, a PET Ligand for the Imidazoline(2) Binding Site in Human Brain. J Nucl Med (2018) 59(10):1597-602. doi: 10.2967/ jnumed.118.208009

176. Calsolaro V, Matthews PM, Donat CK, Livingston NR, Femminella GD, Guedes SS, et al. Astrocyte Reactivity With Late-Onset Cognitive Impairment Assessed In Vivo Using 11C-BU99008 PET and its Relationship With Amyloid Load. Mol Psychiatry (2021). doi: 10.1038/ s41380-021-01193-Z

177. Livingston N, Calsolaro V, Hinz R, Nowell J, Raza S, Gentleman S, et al. Relationship Between Astrocyte Reactivity, Using Novel 11 C-BU99008 PET, and Glucose Metabolism, Grey Matter Volume and Amyloid Load in Cognitively Impaired Individuals. medRxiv (2021). doi: 10.1101/2021.08.10.21261690

178. Venkataraman AV, Keat N, Myers JF, Turton S, Mick I, Gunn RN, et al. First Evaluation of PET-Based Human Biodistribution and Radiation Dosimetry of (11)C-BU99008, a Tracer for Imaging the Imidazoline(2) Binding Site. EJNMMI Res (2018) 8(1):71. doi: 10.1186/s13550-018-0429-x

179. Parker CA, Nabulsi N, Holden D, Lin SF, Cass T, Labaree D, et al. Evaluation of 11C-BU99008, a PET Ligand for the Imidazoline2 Binding Sites in Rhesus Brain. J Nucl Med (2014) 55(5):838-44. doi: 10.2967/jnumed.113.131854

180. Kawamura K, Yamasaki T, Zhang Y, Wakizaka H, Hatori A, Xie L, et al. Change in the Binding of [(11)C]BU99008 to Imidazoline I(2) Receptor Using Brain PET in Zucker Rats. Mol Imaging Biol (2019) 21(1):105-12. doi: 10.1007/s11307-018-1206-y

181. Kawamura K, Shimoda Y, Yui J, Zhang Y, Yamasaki T, Wakizaka H, et al. A Useful PET Probe [(11)C]BU99008 With Ultra-High Specific Radioactivity for Small Animal PET Imaging of I(2)-Imidazoline Receptors in the Hypothalamus. Nucl Med Biol (2017) 45:1-7. doi: 10.1016/j.nucmedbio. 2016.10.005

182. Kawamura K, Shimoda Y, Kumata K, Fujinaga M, Yui J, Yamasaki T, et al. In Vivo Evaluation of a New ${ }^{18} \mathrm{~F}$-Labeled PET Ligand, $\left[{ }^{18} \mathrm{~F}\right] \mathrm{FEBU}$, for the Imaging of $\mathrm{I}_{2}$-Imidazoline Receptors. Nucl Med Biol (2015) 42(4):406-12. doi: 10.1016/j.nucmedbio.2014.12.014

183. Kawamura K, Maeda J, Hatori A, Okauchi T, Nagai Y, Higuchi M, et al. In Vivo and In Vitro Imaging of $\mathrm{I}_{2}$ Imidazoline Receptors in the Monkey Brain. Synapse (2011) 65(5):452-5. doi: 10.1002/syn.20897

184. Kreimerman I, Reyes AL, Paolino A, Pardo T, Porcal W, Ibarra M, et al. Biological Assessment of a 18F-Labeled Sulforhodamine 101 in a Mouse Model of Alzheimer's Disease as a Potential Astrocytosis Marker. Front Neurosci (2019) 13:734. doi: 10.3389/fnins.2019.00734

185. Gerwien H, Hermann S, Zhang X, Korpos E, Song J, Kopka K, et al. Imaging Matrix Metalloproteinase Activity in Multiple Sclerosis as a Specific Marker of Leukocyte Penetration of the Blood-Brain Barrier. Sci Trans Med (2016) 8 (364):364ra152. doi: 10.1126/scitranslmed.aaf8020

186. Ni R, Vaas M, Ren W, Klohs J. Noninvasive Detection of Acute Cerebral Hypoxia and Subsequent Matrix-Metalloproteinase Activity in a Mouse Model of Cerebral Ischemia Using Multispectral-OptoacousticTomography. Neurophotonics (2018) 5(1):15005-10. doi: 10.1117/1.NPh.5. 1.015005

187. Gao M, Wang M, Meyer JA, Peters JS, Zarrinmayeh H, Territo PR, et al. Synthesis and Preliminary Biological Evaluation of [(11)C]methyl (2Amino-5-(Benzylthio)Thiazolo[4,5-D]Pyrimidin-7-Yl)-D-Leucinate for the Fractalkine Receptor (CX(3)CR1). Bioorg Med Chem Lett (2017) 27 (12):2727-30. doi: 10.1016/j.bmcl.2017.04.052

188. Cary BP, Brooks AF, Fawaz MV, Drake LR, Desmond TJ, Sherman P, et al. Synthesis and Evaluation of [(18)F]RAGER: A First Generation SmallMolecule PET Radioligand Targeting the Receptor for Advanced Glycation Endproducts. ACS Chem Neurosci (2016) 7(3):391-8. doi: 10.1021/ acschemneuro.5b00319

189. Zhang Y, Chen K, Sloan SA, Bennett ML, Scholze AR, Keeffe S, et al. An RNA-Sequencing Transcriptome and Splicing Database of Glia, Neurons, and Vascular Cells of the Cerebral Cortex. J Neurosci (2014) 34(36):11929. doi: 10.1523/JNEUROSCI.1860-14.2014

190. Zhang Y, Sloan SA, Clarke LE, Caneda C, Plaza CA, Blumenthal PD, et al. Purification and Characterization of Progenitor and Mature Human Astrocytes Reveals Transcriptional and Functional Differences With Mouse. Neuron (2016) 89(1):37-53. doi: 10.1016/j.neuron.2015.11.013

191. Rupprecht R, Papadopoulos V, Rammes G, Baghai TC, Fan J, Akula N, et al. Translocator Protein $(18 \mathrm{kDa})$ (TSPO) as a Therapeutic Target for Neurological and Psychiatric Disorders. Nat Rev Drug Discov (2010) 9 (12):971-88. doi: $10.1038 / \mathrm{nrd} 3295$

192. Notter T, Schalbetter SM, Clifton NE, Mattei D, Richetto J, Thomas K, et al. Neuronal Activity Increases Translocator Protein (TSPO) Levels. Mol Psychiatry (2020). doi: 10.1038/s41380-020-0745-1

193. Gui Y, Marks JD, Das S, Hyman BT, Serrano-Pozo A. Characterization of the $18 \mathrm{kDa}$ Translocator Protein (TSPO) Expression in Post-Mortem Normal and Alzheimer's Disease Brains. Brain Pathol (2020) 30(1):151-64. doi: 10.1111/bpa.12763

194. Vivash L, O’Brien TJ. Imaging Microglial Activation With TSPO PET: Lighting Up Neurologic Diseases? J Nucl Med (2016) 57(2):165-8. doi: $10.2967 /$ jnumed.114.141713

195. Roivainen A, Någren K, Hirvonen J, Oikonen V, Virsu P, Tolvanen T, et al. Whole-Body Distribution and Metabolism of [N-Methyl-11C](R)-1-(2Chlorophenyl)-N-(1-Methylpropyl)-3-Isoquinolinecarboxamide in Humans; an Imaging Agent for In Vivo Assessment of Peripheral Benzodiazepine Receptor Activity With Positron Emission Tomography. Eur J Nucl Med Mol Imaging (2009) 36(4):671-82. doi: 10.1007/s00259-0081000-1

196. Passamonti L, Tsvetanov KA, Jones PS, Bevan-Jones WR, Arnold R, Borchert RJ, et al. Neuroinflammation and Functional Connectivity in Alzheimer's Disease: Interactive Influences on Cognitive Performance. J Neurosci (2019) 39(36):7218. doi: 10.1523/JNEUROSCI.2574-18.2019

197. Fan Z, Calsolaro V, Atkinson RA, Femminella GD, Waldman A, Buckley C, et al. Flutriciclamide (18f-GE180) PET: First-In-Human PET Study of Novel 
Third-Generation In Vivo Marker of Human Translocator Protein. J Nucl Med (2016) 57(11):1753-9. doi: 10.2967/jnumed.115.169078

198. Felsky D, Roostaei T, Nho K, Risacher SL, Bradshaw EM, Petyuk V, et al. Neuropathological Correlates and Genetic Architecture of Microglial Activation in Elderly Human Brain. Nat Commun (2019) 10(1):409. doi: 10.1038/s41467-018-08279-3

199. Femminella GD, Dani M, Wood M, Fan Z, Calsolaro V, Atkinson R, et al. Microglial Activation in Early Alzheimer Trajectory is Associated With Higher Gray Matter Volume. Neurology (2019) 92(12):e1331-43. doi: $10.1212 / w n l .0000000000007133$

200. Tiwari AK, Ji B, Yui J, Fujinaga M, Yamasaki T, Xie L, et al. [18f]FEBMP: Positron Emission Tomography Imaging of TSPO in a Model of Neuroinflammation in Rats, and In Vitro Autoradiograms of the Human Brain. Theranostics (2015) 5(9):961-9. doi: 10.7150/thno.12027

201. Janssen B, Mach RH. Development of Brain PET Imaging Agents: Strategies for Imaging Neuroinflammation in Alzheimer's Disease. Prog Mol Biol Transl Sci (2019) 165:371-99. doi: 10.1016/bs.pmbts.2019.04.005

202. Janssen B, Vugts DJ, Windhorst AD, Mach RH. PET Imaging of Microglial Activation-Beyond Targeting TSPO. Molecules (2018) 23(3). doi: 10.3390/ molecules 23030607

203. Lin H, Lee E, Hestir K, Leo C, Huang M, Bosch E, et al. Discovery of a Cytokine and its Receptor by Functional Screening of the Extracellular Proteome. Science (2008) 320(5877):807-11. doi: 10.1126/science.1154370

204. Hamilton JA. Colony-Stimulating Factors in Inflammation and Autoimmunity. Nat Rev Immunol (2008) 8(7):533-44. doi: 10.1038/nri2356

205. Murphy MC, Curran GL, Glaser KJ, Rossman PJ, Huston J3rd, Poduslo JF, et al. Magnetic Resonance Elastography of the Brain in a Mouse Model of Alzheimer's Disease: Initial Results. Magn Reson Imaging (2012) 30(4):5359. doi: 10.1016/j.mri.2011.12.019

206. Dubois RN, Abramson SB, Crofford L, Gupta RA, Simon LS, Van De Putte LB, et al. Cyclooxygenase in Biology and Disease. FASEB J (1998) 12 (12):1063-73. doi: 10.1096/fasebj.12.12.1063

207. Choi S-H, Aid S, Bosetti F. The Distinct Roles of Cyclooxygenase-1 and -2 in Neuroinflammation: Implications for Translational Research. Trends Pharmacol Sci (2009) 30(4):174-81. doi: 10.1016/j.tips.2009.01.002

208. Umeozulu S, Young N, Taddei C, Simeon F, Pike V. Chemical Studies Aimed at Developing Improved PET Radioligands for Imaging Brain Cyclooxygenase-2. J Nucl Med (2021) 62(supplement 1):1448.

209. Litchfield M, Wuest M, Glubrecht D, Wuest F. Radiosynthesis and Biological Evaluation of [(18)F]Triacoxib: A New Radiotracer for PET Imaging of COX-2. Mol Pharm (2020) 17(1):251-61. doi: 10.1021/acs.molpharmaceut.9b00986

210. Ji B, Kumata K, Onoe H, Kaneko H, Zhang MR, Seki C, et al. Assessment of Radioligands for PET Imaging of Cyclooxygenase-2 in an Ischemic Neuronal Injury Model. Brain Res (2013) 1533:152-62. doi: 10.1016/j.brainres.2013.08.026

211. Shukuri M, Takashima-Hirano M, Tokuda K, Takashima T, Matsumura K, Inoue $\mathrm{O}$, et al. In Vivo Expression of Cyclooxygenase-1 in Activated Microglia and Macrophages During Neuroinflammation Visualized by PET With 11C-Ketoprofen Methyl Ester. J Nucl Med (2011) 52(7):1094. doi: 10.2967/jnumed.110.084046

212. Evens N, Bosier B, Lavey BJ, Kozlowski JA, Vermaelen P, Baudemprez L, et al. Labelling and Biological Evaluation of [(11)C]methoxy-Sch225336: A Radioligand for the Cannabinoid-Type 2 Receptor. Nucl Med Biol (2008) 35 (7):793-800. doi: 10.1016/j.nucmedbio.2008.07.004

213. Di Virgilio F, Dal Ben D, Sarti AC, Giuliani AL, Falzoni S. The P2X7 Receptor in Infection and Inflammation. Immunity (2017) 47(1):15-31. doi: 10.1016/j.immuni.2017.06.020

214. Cserép C, Pósfai B, Lénárt N, Fekete R, László ZI, Lele Z, et al. Microglia Monitor and Protect Neuronal Function Through Specialized Somatic Purinergic Junctions. Science (2020) 367(6477):528-37. doi: 10.1126/science.aax6752

215. Zrzavy T, Hametner S, Wimmer I, Butovsky O, Weiner HL, Lassmann H. Loss of 'Homeostatic' Microglia and Patterns of Their Activation in Active Multiple Sclerosis. Brain J Neurol (2017) 140(7):1900-13. doi: 10.1093/brain/awx113

216. Badimon A, Strasburger HJ, Ayata P, Chen X, Nair A, Ikegami A, et al. Negative Feedback Control of Neuronal Activity by Microglia. Nature (2020) 586(7829):417-23. doi: 10.1038/s41586-020-2777-8

217. Mildner A, Huang H, Radke J, Stenzel W, Priller J. P2Y(12) Receptor Is Expressed on Human Microglia Under Physiological Conditions
Throughout Development and is Sensitive to Neuroinflammatory Diseases. Glia (2017) 65(2):375-87. doi: 10.1002/glia.23097

218. Fu Z, Lin Q, Hu B, Zhang Y, Chen W, Zhu J, et al. P2X7 PET Radioligand (18)F-PTTP for Differentiation of Lung Tumor From Inflammation. J Nucl Med (2019) 60(7):930-6. doi: 10.2967/jnumed.118.222547

219. Drake LR, Brooks AF, Mufarreh AJ, Pham JM, Koeppe RA, Shao X, et al. Deuterium Kinetic Isotope Effect Studies of a Potential In Vivo Metabolic Trapping Agent for Monoamine Oxidase B. ACS Chem Neurosci (2018) 9 (12):3024-7. doi: 10.1021/acschemneuro.8b00219

220. Tesson F, Limon-Boulez I, Urban P, Puype M, Vandekerckhove J, Coupry I, et al. Localization of I2-Imidazoline Binding Sites on Monoamine Oxidases. J Biol Chem (1995) 270(17):9856-61. doi: 10.1074/jbc.270.17.9856

221. Parker CA, Nabulsi N, Holden D, Lin S-F, Cass T, Labaree D, et al. Tyacke: Evaluation of 11C-BU99008, a PET Ligand for the Imidazoline2 Binding Sites in Rhesus Brain. J Nucl Med (2014) 55(5):838. doi: 10.2967/ jnumed.113.131854

222. Hansson O. Biomarkers for Neurodegenerative Diseases. Nat Med (2021) 27 (6):954-63. doi: 10.1038/s41591-021-01382-x

223. Ni R, Gillberg PG, Bogdanovic N, Viitanen M, Myllykangas L, Nennesmo I, et al. Amyloid Tracers Binding Sites in Autosomal Dominant and Sporadic Alzheimer's Disease. Alzheimers Dement (2017) 13(4):419-30. doi: 10.1016/ j.jalz.2016.08.006

224. Perani D, Iaccarino L, Jacobs AH. Application of Advanced Brain Positron Emission Tomography-Based Molecular Imaging for a Biological Framework in Neurodegenerative Proteinopathies. Alzheimers Dement (Amst) (2019) 11:327-32. doi: 10.1016/j.dadm.2019.02.004

225. Perani D, Iaccarino L, Lammertsma AA, Windhorst AD, Edison P, Boellaard R, et al. A New Perspective for Advanced Positron Emission TomographyBased Molecular Imaging in Neurodegenerative Proteinopathies. Alzheimers Dement (2019) 15(8):1081-103. doi: 10.1016/j.jalz.2019.02.004

226. Nutma E, Ceyzériat K, Amor S, Tsartsalis S, Millet P, Owen DR, et al. Cellular Sources of TSPO Expression in Healthy and Diseased Brain. Eur J Nucl Med Mol Imaging (2021). doi: 10.1007/s00259-020-05166-2

227. Nutma E, Stephenson JA, Gorter RP, de Bruin J, Boucherie DM, Donat CK, et al. A Quantitative Neuropathological Assessment of Translocator Protein Expression in Multiple Sclerosis. Brain J Neurol (2019) 142(11):3440-55. doi: 10.1093/brain/awz287

228. Tournier BB, Tsartsalis S, Ceyzériat K, Medina Z, Fraser BH, Grégoire MC, et al. Fluorescence-Activated Cell Sorting to Reveal the Cell Origin of Radioligand Binding. J Cereb Blood Flow Metab (2020) 40(6):1242-55. doi: $10.1177 / 0271678 \times 19860408$

229. Pannell M, Economopoulos V, Wilson TC, Kersemans V, Isenegger PG, Larkin JR, et al. Imaging of Translocator Protein Upregulation Is Selective for Pro-Inflammatory Polarized Astrocytes and Microglia. Glia (2020) 68 (2):280-97. doi: 10.1002/glia.23716

230. Cagnin A, Brooks DJ, Kennedy AM, Gunn RN, Myers R, Turkheimer FE, et al. In-Vivo Measurement of Activated Microglia in Dementia. Lancet (2001) 358(9280):461-7. doi: 10.1016/s0140-6736(01)05625-2

231. Yokokura M, Mori N, Yagi S, Yoshikawa E, Kikuchi M, Yoshihara Y, et al. In Vivo Changes in Microglial Activation and Amyloid Deposits in Brain Regions With Hypometabolism in Alzheimer's Disease. Eur J Nucl Med Mol Imaging (2011) 38(2):343-51. doi: 10.1007/s00259-010-1612-0

232. Wiley CA, Lopresti BJ, Venneti S, Price J, Klunk WE, DeKosky ST, et al. Carbon 11-Labeled Pittsburgh Compound B and Carbon 11-Labeled (R)PK11195 Positron Emission Tomographic Imaging in Alzheimer Disease. Arch Neurol (2009) 66(1):60-7. doi: 10.1001/archneurol.2008.511

233. Groom GN, Junck L, Foster NL, Frey KA, Kuhl DE. PET of Peripheral Benzodiazepine Binding Sites in the Microgliosis of Alzheimer's Disease. J Nucl Med (1995) 36(12):2207-10.

234. Albrecht DS, Sagare A, Pachicano M, Sweeney MD, Toga A, Zlokovic B, et al. Early Neuroinflammation is Associated With Lower Amyloid and Tau Levels in Cognitively Normal Older Adults. Brain Behav Immun (2021) 94:299307. doi: 10.1016/j.bbi.2021.01.010

235. Ji B, Chen C-J, Bando K, Ashino H, Shiraishi H, Sano H, et al. Distinct Binding of Amyloid Imaging Ligands to Unique Amyloid- $\beta$ Deposited in the Presubiculum of Alzheimer's Disease. J Neurochem (2015) 135(5):859-66. doi: $10.1111 /$ jnc. 13293 
236. Kong Y, Huang L, Li W, Liu X, Zhou Y, Liu C, et al. The Synaptic Vesicle Protein 2a Interacts With Key Pathogenic Factors in Alzheimer's Disease: Implications for Treatment. Front Cell Dev Biol (2021) 9:1555. doi: 10.3389/ fcell.2021.609908

Conflict of Interest: The authors declare that the research was conducted in the absence of any commercial or financial relationships that could be construed as a potential conflict of interest.

Publisher's Note: All claims expressed in this article are solely those of the authors and do not necessarily represent those of their affiliated organizations, or those of the publisher, the editors and the reviewers. Any product that may be evaluated in this article, or claim that may be made by its manufacturer, is not guaranteed or endorsed by the publisher.

Copyright (C) 2021 Zhou, Ji, Kong, Qin, Ren, Guan and Ni. This is an open-access article distributed under the terms of the Creative Commons Attribution License (CC BY). The use, distribution or reproduction in other forums is permitted, provided the original author(s) and the copyright owner(s) are credited and that the original publication in this journal is cited, in accordance with accepted academic practice. No use, distribution or reproduction is permitted which does not comply with these terms. 